\title{
From microbes to macrofauna: an integrated study of deep benthic communities and their response to environmental variables along the Malta Escarpment (Ionian Sea)
}

\author{
ELISA BALDRIGHI ${ }^{1}$, STEFANO ALIANI ${ }^{2}$, ALESSANDRA CONVERSI ${ }^{2,3,4}$, \\ MARC LAVALEYE $^{5}$, MIRENO BORGHINI ${ }^{2}$ and ELENA MANINI ${ }^{1}$ \\ ${ }^{1}$ Institute for Marine Sciences, National Research Council (ISMAR-CNR), Largo Fiera della Pesca, 60122 Ancona, Italy. \\ E-mail: e.manini@ismar.cnr.it \\ ${ }^{2}$ Institute of Marine Sciences, National Research Council (ISMAR-CNR), Forte S. Teresa, 19036 Lerici, Italy. \\ ${ }^{3}$ Marine Institute, Plymouth University, Plymouth, PL4 8AA, UK. \\ ${ }^{4}$ Sir Alister Hardy Foundation for Ocean Science (SAHFOS), Citadel Hill, The Hoe, Plymouth PL1 2PB, UK. \\ ${ }^{5}$ Department of Marine Ecology, Royal Netherlands Institute for Sea Research (NIOZ), Texel, The Netherlands.
}

SUMMARY: A comparative study for abundance, biomass and diversity was carried out for the prokaryote, meiofauna and macrofauna communities at three depth stations (1200, 1800 and $2100 \mathrm{~m}$ ) along the Malta Escarpment (Mediterranean Sea). Our investigation showed a two-fold increase with depth in prokaryote abundance; the contribution of prokaryote biomass to the total benthic biomass was predominant at all depths. Bacteria were the dominant prokaryote component and Archaea formed a considerable fraction $(20 \%-30 \%)$ of the prokaryote assemblages. The meio- and macrofauna abundances and meiofauna biomass did not decrease significantly with depth but macrofauna biomass did. The $\alpha$ diversity did not follow a clear bathymetric trend for both nematode and macrofauna species. Probably because of the large number of eurybathic nematode genera, nor did the turnover diversity in nematode composition change down the depth gradient. Conversely, for the macrofauna there was a perceptible change in community composition between the shallowest station and the two deeper stations. Food availability affected only the macrobenthic component. The increase in the prokaryote organisms with depth and the dominance of nematodes and macrofauna deposit feeders suggest active grazing by the two benthic components on microbes. This would transfer energy to the higher trophic levels through the microbial compartment.

Keywords: prokaryote, meiofauna, macrofauna, abundance, biomass, diversity, Malta Escarpment, Mediterranean Sea.

RESUMEN: DESDE MICROORGANISMOS A LA MACROFAUNA: UN ESTUDIO COMPARATIVO DE LAS COMUNIDADES BENTÓNICAS PROFUNDAS Y SU RESPUESTA A LAS VARIABLES AMBIENTALES A LO LARGO DEL TALUd DE MALTA (MAR JóNICO). - Se llevó a cabo un estudio comparativo de las comunidades de procariotas, meiofauna y macrofauna sobre la abundancia, biomasa y diversidad. Fue realizado en tres estaciones en varias profundidades (1200, 1800 y $2100 \mathrm{~m})$ a lo largo del talud de Malta (mar Mediterráneo). Nuestra investigación muestra que, aumentando la profundidad, la abundancia de procariotas se duplica. La contribución de la biomasa procariota al total de la biomasa bentónica predominó en todas las profundidades. Las bacterias eran la fracción procariota dominante y junto con los Archaea representaban al 20-30\% del total de procariotas. Por otra parte la abundancia de la meiofauna y macrofauna y la biomasa de la meiofauna no disminuían significativamente con la profundidad, mientras que la biomasa de la macrofauna sí lo hacía. La diversidad $\alpha$ no siguió una tendencia batimétrica muy clara para las especies de los nematodos y macrofauna. Probablemente debido a la gran abundancia de géneros de nematodos eurybatiales, la tasa derenovación de la diversidad en la composición de nematodos tampoco cambió por el gradiente de profundidad. En cambio, para la macrofauna hubo un cambio apreciable en la composición de la comunidad entre la estación más superficial y las dos estaciones más profundas. La disponibilidad de alimentos afectó sólo al componente macrobentónico. El aumento con la profundidad de los organismos procariotas, el dominio de los nematodos y la macrofauna que se alimenta de los materiales depositados sugieren un medio activo para los dos componentes bentónicos microbianos. Esto daría lugar a una transferencia de energía a niveles tróficos superiores a través del compartimento microbiano.

Palabras clave: procariotas, meiofauna, macrofauna, abundancia, biomasa, diversidad, talud de Malta, mar Mediterráneo. 


\section{INTRODUCTION}

The continental slopes are the areas of steep descent from the continental shelf to the ocean floor and constitute less than $20 \%$ of the oceans of the world (Levin and Sibuet 2012). Although estimates remain controversial, continental margin environments might account for more than $20 \%$ of total marine productivity, and for a significantly greater proportion of organic matter export, with potentially up to $50 \%$ of the biological pump transfer of organic carbon to the deep ocean and $15 \%$ of the net air-to-sea $\mathrm{CO}_{2}$ flux (Mackenzie and Lerman 2006). In addition, at least $80 \%$ of the mass of terrigenous materials reaching the ocean is deposited in continental margin environments, and more than $90 \%$ of the total organic carbon accumulation in the ocean occurs in continental margin sediments (Mackenzie and Lerman 2006). Furthermore, these sediments host a large proportion of the unknown biodiversity and are repositories of deep-sea biomass (Ramirez-Llodra et al. 2010). The enhanced levels of biodiversity along slopes are hypothesized to be a source of biodiversity for continental shelves and deeper basins as well (Danovaro et al. 2009). Recently it has been demonstrated that higher levels of biodiversity can sustain a higher ecosystem functioning and efficiency (Danovaro et al. 2008a). Indeed it is extremely important to clarify the sources of deep-sea biodiversity and to identify the mechanisms that may drive this diversity and its distribution (Levin and Sibuet 2012).

For all these reasons, continental slopes are remarkable sites for investigations of the variability of the standing stock and of the diversity of all of the sizeclass components of the benthic fauna, as well as of the environmental variables (e.g. hydrostatic pressure and food availability) that are the potential drivers for these communities. Previous investigations have shown that the distribution, biomass and structure of deep benthic communities along depth gradients of continental margins are highly variable from site to site and at different spatial scales (Galil 2004, Guilini et al. 2011).

On the whole, there is a considerable decrease in meiofauna and macrofauna abundance and biomass with increasing water depth, which represents a wellknown pattern in benthic marine ecology (Rex et al. 2006, Ramirez-Llodra et al. 2010). However, this general rule does not apply to all size classes of deep-sea communities. For instance, the number of bacterial and archaeal operational taxonomic units does not appear to change significantly with increasing water depth (Rex et al. 2006, Danovaro et al. 2010). A single general driver explaining the spatial variation of benthic biodiversity is clearly reductive (Coll et al. 2010), and various biological and environmental factors have been proposed to explain changes in species diversity with depth. These have included habitat heterogeneity, food resources, oxygen availability, temperature and water currents. However, for each deep-sea benthic group of organisms (from microfauna to megafauna), these fac- tors can act in different combinations, which can mask other local or regional factors and generate unpredictable biotic responses (Levin et al. 2001).

The different benthic size components (microfauna, meiofauna and macrofauna) of the slope ecosystems of the oceans throughout the world have been investigated in different studies (e.g. Kröncke et al. 2000, Galéron et al. 2000, Rex et al. 2006), although there is still little information available for the Mediterranean Sea (Albertelli et al. 1999; Danovaro et al. 2010). However, an integrated analysis of size-class groups of benthic species that belong to different functional groups (Gage and Tyler 1991, Flach 1999) is seen as the best approach to understand deep-sea ecology and functioning (Flach 1999, Galéron et al. 2000). Furthermore in a scenario of developing understanding of the critical role of biodiversity for the functioning of marine ecosystems, it is crucial to clarify how biodiversity varies in space and which mechanisms/factors are responsible for these variations (Narayanaswamy et al. 2010).

To accomplish this overall objective, we sampled the microfauna, meiofauna and macrofauna and measured the key environmental variables at three different depths $(1200,1800$ and $2100 \mathrm{~m})$ along the continental margin of the Malta Escarpment in the Ionian Sea (Mediterranean Sea) during the Tyrrmounts09 expedition (May 2009) on the R/V Urania.

Although this sampling was across a relatively short depth transect (only three depths, according to limited ship time), the aims of this investigation were the following:

(i) To describe the benthic size-class components in terms of abundance, biomass, community structure and diversity in relation to the different water depths, and to determine whether they show co-variations.

(ii) To investigate potential relationships within the benthic communities between any variations in the three biotic components and the three known potential drivers (depth, grain size and food availability).

\section{MATERIALS AND METHODS}

\section{Study site and sampling}

The sampling was carried out along the Malta Escarpment, to the southeast of Capo Passero (Fig. 1), from 8 to 19 May, 2009. The Malta Escarpment is an area of continental slope in the Ionian Sea with a drop of more than $3000 \mathrm{~m}$, and it is the dominant morphological offshore feature of eastern Sicily; it separates the Hyblean-Malta plateau from the deep Ionian Basin (Argnani and Bonazzi 2005). The Malta Escarpment has been the subject of many geological investigations (e.g. Catalano et al. 2001, Argnani and Bonazzi 2005), although little data and information are currently available relating to its deep benthic communities (e.g. meiofauna, macrofauna).

Sediment samples were collected at three depths (hereinafter also referred to as the depth stations) along 


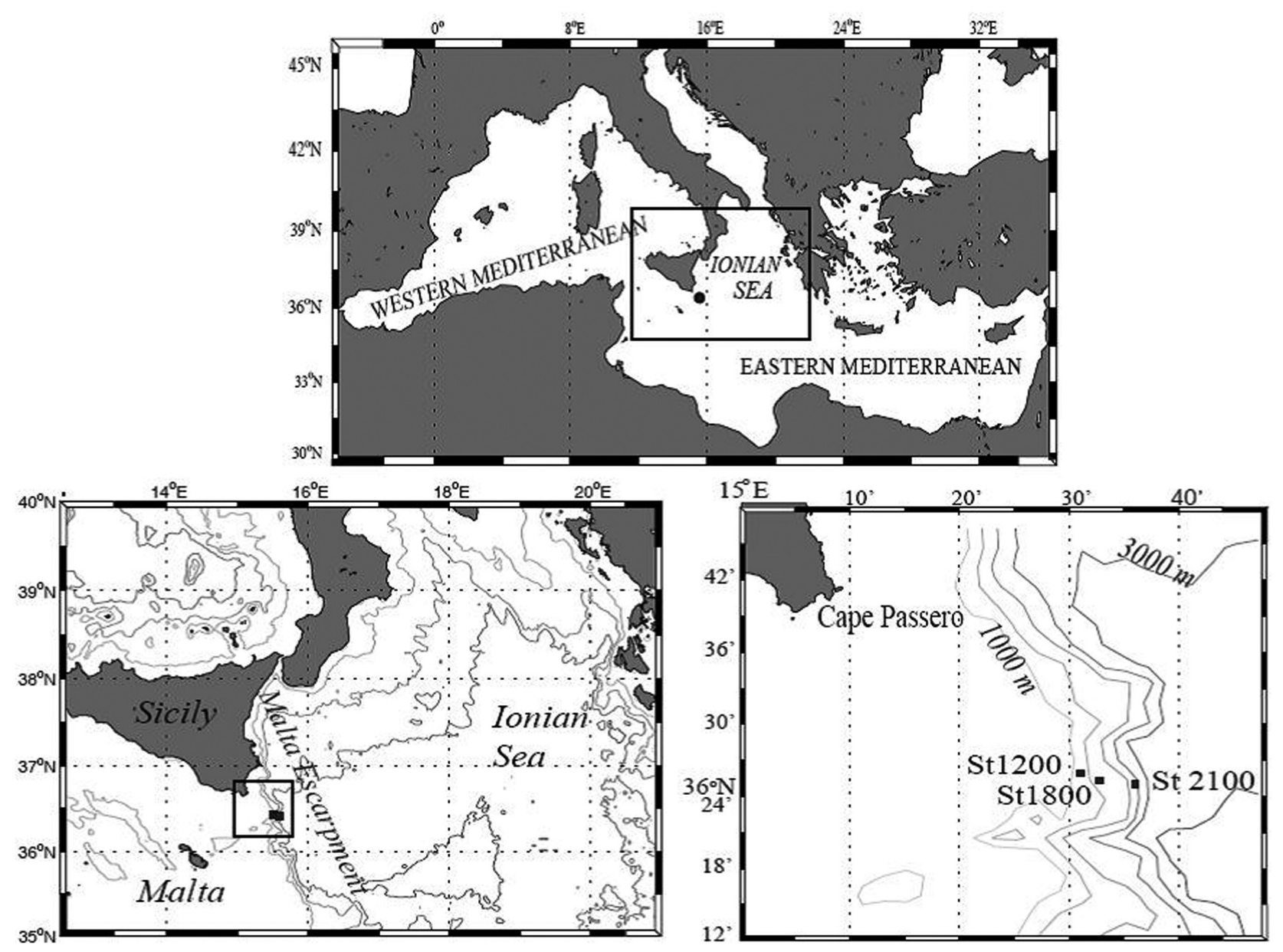

FIG. 1. - Map of the study area along the Malta Escarpment, showing the three water depth stations: St1200, St1800, St2100.

a single transect: $1200 \mathrm{~m}, 1800 \mathrm{~m}$ and $2100 \mathrm{~m}$ for a total regional distance between sites of 9 kilometres $(\sim 3$ and $\sim 6 \mathrm{~km}$ between the 1200 and $1800 \mathrm{~m}$ stations and between the 1800 and $2100 \mathrm{~m}$ stations, respectively). At each depth station, three independent replicates were collected for the analysis of the macrofauna, using a circular box corer that covered an area of $803.84 \mathrm{~cm}^{2}$ (inner diameter, $32 \mathrm{~cm}$ ). Sub-samples of the prokaryotes, meiofauna and sediments (for the measurement of organic matter content and sediment grain size) were taken from three separate box corer hauls from each station.

\section{Measured variables}

The temperature, conductivity and dissolved oxygen were measured at each depth station using a SeaBIRD 911 CTD probe. As performed for the macrofauna (see below), the grain-size analyses were done on the top 20 $\mathrm{cm}$ of sediment for each replica. These samples were dry-sieved to separate the coarser part $(\geq 63 \mu \mathrm{m})$ from the finer part $(<63 \mu \mathrm{m})$, which was analysed with a Helos/KF Sympatec laser spectrometer. According to many studies conducted in the deep sea (e.g. Pusceddu et al. 2010, Pape et al. 2013) and for an easier comparison with other work, total protein, carbohydrate, lipid, chlorophyll- $a$ and phaeopigment contents were determined from superficial $(0-1 \mathrm{~cm})$ sediment samples $( \pm 1$ g) and following the standard techniques (Danovaro et al. 1999). The carbohydrate (CHO), protein (PRT) and lipid (LIP) concentrations were converted into carbon equivalents using the conversion factors $0.40,0.49$ and $0.75 \mu \mathrm{gC} \mu \mathrm{g}^{-1}$, respectively, and normalized to sediment dry weight after desiccation $\left(60^{\circ} \mathrm{C}, 24 \mathrm{~h}\right)$. The biopolymeric organic carbon (BPC) was calculated as the sum of the carbon equivalents of protein, lipid and carbohydrate (Fabiano et al. 1995). Chloroplast pigment equivalents (CPEs) were defined as the sum of the chlorophyll- $a$ and phaeopigment concentrations.

As reported in Danovaro (2010), the total prokaryote counts were determined from the top $1 \mathrm{~cm}$ layer of the sediment using staining with acridine orange (Luna et al. 2002) and expressed as cells $\mathrm{m}^{-2}$ and cells $\mathrm{g}^{-1}$ (Fig. 1a, supplementary information Table S1). The prokaryote biomass was estimated using an ocular micrometer and is expressed as $\mathrm{mgC} \mathrm{m}^{-2}$ and $\mu \mathrm{gC}^{-1}$ (supplementary information Table S1), with the assignment of the prokaryote cells to different size classes 
based on their maximum width and length (Fry 1990); these were then converted into biovolumes using the estimate of the average carbon content of $310 \mathrm{fgC}^{-3} \mathrm{~m}^{-3}$ (Fry 1990). The total numbers and biomass were normalized to the sediment dry weight after desiccation $\left(60^{\circ} \mathrm{C}\right.$ for $\left.24 \mathrm{~h}\right)$.

To investigate the prokaryote community structure, fluorescence in situ hybridization (FISH) was used, with rRNA-targeted oligonucleotide probes and signal amplification (catalysed reporter deposition; CARD), as previously described (Molari and Manini 2012). The oligonucleotide probes used were EUB338mix (EUB338, 5'-GCTGCCTCCCGTAGGAGT-3', EUB338-II, 5'-GCAGCCACCCGTAGGTGT-3', and EUB338-III, 5'-GCTGCCACCCGTAGGTGT-3') to target total Bacteria, ARCH915 (5'- GTGCTCCCCCGCCAATTCCT-3') to target total Archaea, CREN537 (5'-TGACCACTTGAGGTGCTG-3') to target Crenarchaeota Marine Group I, EURY806 (5'-CACAGCGTTTACACCTAG-3') to target Euryarchaeota Marine Group II, and NON338 (5'-ACTCCTACGGGAGGCAGC-3') as negative control.

For the meiofauna analysis, sediment was taken from each box corer using a plexiglas tube with a $3.6-\mathrm{cm}$ internal diameter; this sample was immediately fixed with $4 \%$ buffered formalin and rose bengal. For our purposes, only the sediment from the top $5 \mathrm{~cm}$ was sieved through $300 \mu \mathrm{m}$ and $20 \mu \mathrm{m}$ mesh, as most of the meiofauna are usually concentrated in the top $2 \mathrm{~cm}$, or at least in the top $0 \mathrm{~cm}$ to $6 \mathrm{~cm}$ (Tselepides et al. 2004). The fraction remaining on the $20 \mu \mathrm{m}$ sieve was resuspended and centrifuged with using Ludox HS40 (Danovaro, 2010). The meiofauna specimens were counted (individuals [ind] $\mathrm{m}^{-2}$ and ind $10 \mathrm{~cm}^{-2}$; supplementary information Table S1) and identified to their major taxa under a stereomicroscope. One hundred nematodes from each replicate (or all of the nematodes where there were fewer than 100 specimens) were hand-picked and mounted on permanent slides for the analysis of nematode diversity. The nematodes were identified to the species level (due to the presence of many unknown deep-sea species, the species level is indicated, for example, as sp1, sp2, sp3, etc.) according to Platt and Warwick (1983), Warwick et al. (1998), and the NeMys database (Deprez et al. 2005). The nematode volumes and biomass $\left(\mathrm{mgC} \mathrm{m}^{-2}\right.$ and $\mu \mathrm{gC} 10 \mathrm{~cm}^{-2}$; Supplementary Information Table S1) were calculated using the Andrassy (1956) formulae, and the nematode wet weights were converted into carbon biomass according to Jensen (1984). Then nematode feeding types $(1 \mathrm{~A}, 1 \mathrm{~B}, 2 \mathrm{~A}, 2 \mathrm{~B})$ were determined following the classification provided by Wieser (1953). The nematode trophic diversity index (ITD; Heip et al. 1985) and maturity index (Bongers 1990) were calculated. The nematode trophic diversity indices ranged from 0.25 (high diversity; all trophic groups present) to 1.00 (low diversity; only one group present). The maturity index is used to estimate the stability of a community, and this index can range from 1 (r-strategy nematodes) to 5 (K-strategy nematodes).
Accordingly with different works on deep-sea macrobenthos, in which the first $15-20 \mathrm{~cm}$ were usually considered (e.g. Flach and de Bruin 1999, Witte 2000), the macrofauna was sampled in the first $20 \mathrm{~cm}$ of the sediment of all of the box corer samples (three replicates per depth station). The sediments were gently washed over $300 \mu \mathrm{m}$ mesh size, and the part that remained was fixed in borax-buffered seawater with $10 \%$ formalin, and stained with rose bengal before sorting in the laboratory. In the present study, these macrofauna samples included large Nematoda, Copepoda and Ostracoda. All of the organisms were counted and identified under a stereomicroscope to the lowest possible taxonomic level, to provide abundance (ind $\mathrm{m}^{-2}$ ) values per species. The biomass was measured as mg wet weight $\mathrm{m}^{-2}$ and then converted to $\mathrm{mgC} \mathrm{m}{ }^{-2}$ using the conversion factors of Rowe et al. (1991). Four major macrofauna trophic groups were identified, according to the literature (Sars 1882, Norman and Stebbing 1886, Fauchald and Jumars 1979, Gage and Tyler 1991): surface deposit feeders; subsurface deposit feeders; carnivores/scavengers; and filter feeders/suspension feeders.

The nematode and macrofauna species diversities were measured using the H' log-base 2 Shannon-Wiener index (Shannon and Weaver 1949) and the evenness J' index (Pielou 1975). The species richness was calculated as the total number of species collected at each depth station. The species abundance data were converted into rarefaction diversity indices (Sanders 1968, as modified by Hurlbert 1971), and the expected number of species $\operatorname{ES}(n)$ for a theoretical sample of $n=51$ nematodes and $n=31$ macrobenthic individuals was calculated for each depth station.

For the estimation of the meiofaunal and macrofaunal diversity and feeding mode, we are aware of the weakness of the results due to the problem that many macrofaunal organisms have been recognized at a higher taxonomic level and for the meiofauna only the group of nematodes has been taken in consideration, even if it was always the most abundant and usually considered as representative of the whole community (Danovaro 2010).

\section{Statistical analyses}

To test for differences in the biological and environmental variables according to the three water depths, one-way analysis of variance (ANOVA) was applied using the STATISTICA8 software. Prior to the analyses, the homogeneity of variance was tested with the Cochran test, and when necessary, the data were appropriately transformed. When significant differences were encountered, a Tukey post hoc comparison test $($ at $\mathrm{p}<0.05)$ was performed.

Statistical differences in the nematode and macrobenthic species compositions and community structure compositions of the major taxa (i.e. turnover diversity) among the investigated depths were 
TABLE 1. - Sediment variables for the three increasing water depths along the Malta Escarpment. Data are means \pm standard deviation. CPE, chloroplast pigment equivalent; PRT/CHO, protein-to-carbohydrate ratio; BPC, biopolymeric organic carbon.

\begin{tabular}{lccccccccc}
\hline $\begin{array}{l}\text { Depth } \\
(\mathrm{m})\end{array}$ & \%sand & \%silt & \%clay & $\begin{array}{c}\text { CPE } \\
\left(\mu \mathrm{g} \mathrm{g}^{-1}\right)\end{array}$ & $\begin{array}{c}\text { Proteins } \\
\left(\mathrm{mg} \mathrm{g}^{-1}\right)\end{array}$ & $\begin{array}{c}\text { Carbohydrates } \\
\left(\mathrm{mg} \mathrm{g}^{-1}\right)\end{array}$ & $\begin{array}{c}\text { Lipids } \\
\left(\mathrm{mg} \mathrm{g}^{-1}\right)\end{array}$ & PRT/CHO & $\begin{array}{c}\text { BPC } \\
\left(\mathrm{mgC} \mathrm{g}^{-1}\right)\end{array}$ \\
1200 & 2.3 & 28.7 & 63.2 & $4.15 \pm 0.59$ & $1.67 \pm 0.28$ & $0.45 \pm 0.08$ & $0.86 \pm 0.23$ & $3.68 \pm 0.14$ & $1.64 \pm 0.33$ \\
1800 & 0.3 & 30.9 & 62.4 & $8.35 \pm 0.46$ & $1.58 \pm 0.20$ & $0.54 \pm 0.03$ & $0.56 \pm 0.02$ & $2.92 \pm 0.37$ & $1.41 \pm 0.09$ \\
2100 & 1.6 & 34.5 & 56.5 & $1.63 \pm 0.25$ & $1.27 \pm 0.07$ & $0.60 \pm 0.18$ & $0.32 \pm 0.08$ & $2.20 \pm 0.55$ & $1.11 \pm 0.12$ \\
\hline
\end{tabular}

detected using ANOSIM analysis. All absolute data were presence/absence transformed prior to analyses, and a similarity matrix based on Bray-Curtis similarity was produced. One-way similarity percentage (SIMPER), non-parametric, statistical routines were conducted on the presence/absence transformed data using Bray-Curtis similarity matrices to determine which meiofauna or macrofauna taxa contributed most to the dissimilarities between stations at different depths. Non-metric multi-dimensional scaling analysis was performed (Plymouth Routines In Multivariate Ecological Research; PRIMER 6; Plymouth Marine Laboratory, UK) to obtain graphic visualization of the similarities (Bray-Curtis) among the macrofauna and nematode assemblages of the depth stations.

Spearman rank correlation analysis was initially carried out to identify the relationships between the prokaryote, meiofauna and macrofauna abundances, biomass, trophic structures, and diversity indices (for nematodes and macrobenthic organisms) and the investigated environmental parameters (depth, grain size and organic matter content). Non-parametric multiple regression analysis (McArdle and Anderson 2001) was performed to detect possible correlations between biological descriptors (abundance, biomass, community trophic structure and diversity indices) and environmental variables (depth, grain size and organic matter content), using distance-based multivariate analysis for a linear model (DISTLM), with forward selection of predictor variables (i.e. environmental variables) carried out with tests by permutation (Anderson, M.J., University of Auckland, New Zealand). The multiple regression tests were based on Bray-Curtis dissimilarities (untransformed data); $\mathrm{p}$ values were obtained by 4999 permutations of the original data. ANOSIM and SIMPER analyses were performed using the PRIMER 6 software package.

\section{RESULTS}

\section{Environmental parameters}

The water mass along the Malta Escarpment from the shelf to $3000 \mathrm{~m}$ depth was homogeneous, with temperatures ranging from $13.50^{\circ} \mathrm{C}$ to $13.75^{\circ} \mathrm{C}$, and salinity ranging from 38.74 to 38.76 . The dissolved oxygen content ranged from $4.13 \mathrm{ml} \mathrm{l}^{-1}$ to $4.30 \mathrm{ml} \mathrm{l}^{-1}$. The velocity of the currents was 0.05 to $0.10 \mathrm{~m} \mathrm{~s}^{-1}$. Most of the sediments were clay (on average, $60.7 \%$ ), followed by silt $(31.4 \%)$ and small amounts of sand $(<2.5 \%)$, at all three depths (Table 1).
TABLE 2. - Output of one-way ANOVA and Tukey post hoc tests carried out across the three increasing water depths, to determine the significances of the differences in the sediment organic matter concentrations and benthic components. F, ANOVA F statistic; p, probability level, as $* * *=\mathrm{p}<0.001, * *=\mathrm{p}<0.01, *=\mathrm{p}<0.05$, and $\mathrm{ns}$, not significant. Tukey post hoc tests specified as significant differences between stations. CPE, chloroplast pigment equivalent; PRT/ $\mathrm{CHO}$, protein-to-carbohydrate ratio; $\mathrm{BPC}$, biopolymeric organic carbon; ES(51), expected species number; H' $\left(\log _{2}\right)$, Shannon diversity index $\log _{2}$.

\begin{tabular}{|c|c|c|c|}
\hline Variables & $\mathrm{F}$ & $\mathrm{P}$ & Tukey post-hoc \\
\hline Total phytopigments & 164.5 & $* * *$ & $1200<1800>2100$ \\
\hline Proteins & 3.36 & ns & $\mathrm{ns}$ \\
\hline Carbohydrates & 1.3 & ns & ns \\
\hline Lipids & 10.63 & ** & $1200>2100$ \\
\hline Prot:Carb ratio & 10.84 & $* *$ & $1200>2100$ \\
\hline $\mathrm{C}$ biopolymeric & 4.83 & ns & ns \\
\hline Prokaryotes density & 8.46 & * & $1200<1800<2100$ \\
\hline Prokaryotes biomass & 25.78 & $* *$ & $1200<1800<2100$ \\
\hline$\%$ EUB & 0.62 & ns & ns \\
\hline$\%$ ARCH & 3.79 & $\mathrm{~ns}$ & $\mathrm{~ns}$ \\
\hline$\%$ EURY & 4.12 & ns & $\mathrm{ns}$ \\
\hline$\%$ CREN & 6.69 & $*$ & $1800>2100$ \\
\hline Meiofauna density & 0.61 & $\mathrm{~ns}$ & $\mathrm{~ns}$ \\
\hline Meiofauna biomass & 0.35 & ns & $\mathrm{ns}$ \\
\hline $\mathrm{n}^{\circ} \mathrm{TAXA}$ & 8.45 & * & $1800>1200$ \\
\hline IDT & 0.19 & ns & $\mathrm{ns}$ \\
\hline MI & 0.18 & ns & ns \\
\hline $\mathrm{J}^{\prime}$ & 0.13 & ns & $\mathrm{ns}$ \\
\hline $\mathrm{ES}(51)$ & 1.72 & ns & $\mathrm{ns}$ \\
\hline$H^{\prime}\left(\log _{2}\right)$ & 3.62 & ns & $\mathrm{ns}$ \\
\hline SR & 0.57 & ns & ns \\
\hline $1 \mathrm{~A} \%$ & 6.84 & $*$ & $1800>1200$ \\
\hline $1 \mathrm{~B} \%$ & 2.8 & ns & ns \\
\hline $2 \mathrm{~A} \%$ & 28.95 & $* * *$ & $1200<1800>2100$ \\
\hline $2 \mathrm{~B} \%$ & 6.61 & $*$ & $1200>1800$ \\
\hline Macrofauna density & 0.67 & ns & ns \\
\hline Macrofauna biomass & 7.74 & $*$ & $1200>2100$ \\
\hline $\mathrm{n}^{\circ} \mathrm{TAXA}$ & 1 & ns & $\mathrm{ns}$ \\
\hline SR & 0.64 & ns & ns \\
\hline $\mathrm{J}^{\prime}$ & 0.15 & ns & $\mathrm{ns}$ \\
\hline $\mathrm{ES}(31)$ & 0.37 & ns & ns \\
\hline$H^{\prime}\left(\log _{2}\right)$ & 0.5 & ns & $\mathrm{ns}$ \\
\hline $\mathrm{SDF} \%$ & 0.73 & ns & $\mathrm{ns}$ \\
\hline SSDF $\%$ & 2.77 & ns & $\mathrm{ns}$ \\
\hline $\mathrm{CNV} / \mathrm{SCV} \%$ & 0.67 & ns & $\mathrm{ns}$ \\
\hline $\mathrm{FF} / \mathrm{SF} \%$ & 2.8 & ns & ns \\
\hline
\end{tabular}

The total phytopigments expressed as the CPEs are reported in Table 1 . The CPEs differed significantly between all of the depths (Table 2), with the highest values at $1800 \mathrm{~m}$ depth.

The distributions of the biochemical components of the sedimentary organic matter showed different patterns for all of the variables investigated (Table 1). Proteins formed the dominant class of organic compounds in the top $1 \mathrm{~cm}$ of the sediments, with $c a$. threefold higher concentrations than the carbohydrates and 
lipids. While the total protein and total carbohydrate concentrations did not differ significantly between the depth stations (Table 2), the total lipid concentrations showed a significantly lower concentration at the deepest station $(2100 \mathrm{~m}$; Tables 1,2$)$. The BPC defines the sum of the protein, carbohydrate and lipid components, and its level represents an indicator of the food availability in the sediment. The BPC distribution mirrored that of the dominant class, protein (Table 1). The protein-to-carbohydrate ratio (Table 1, PRT/ $\mathrm{CHO}$ ) is indicative for both the aging and the quality of the organic matter content. Here values of this ratio greater than 1 indicate relative high quality and high food availability for organisms (Pusceddu et al. 2010). This protein-to-carbohydrate ratio in the present study significantly decreased with increasing depth (Table 2, PRT/CHO), although the mean values remained greater than 1 at all depths (Table 1, PRT/CHO), indicating high food quality for all of these depth stations.

\section{Benthic standing stocks}

The total benthic prokaryote abundance and biomass (Fig. 2a, supplementary information Table S1) almost doubled with depth, from $1.83 \pm 0.27 \times 10^{12}$ cells $\mathrm{m}^{-2}$ to $3.34 \pm 0.71 \times 10^{12}$ cells $\mathrm{m}^{-2}$, and from $59.23 \pm 4.99$ $\mathrm{mgC} \mathrm{m} \mathrm{m}^{-2}$ to $117.58 \pm 16.37 \mathrm{mgC} \mathrm{m}^{-2}$, respectively. Prokaryotes were the only biotic component to show any significant increase with depth (Table 2).

The meiofauna abundance showed no clear bathymetric trend (Fig. 2b, supplementary information, Table S1), although it showed a pronounced inter-replica variability, especially for the shallowest depth station $(1200 \mathrm{~m})$. The mean values of the meiobenthic abundance ranged from $1.8 \pm 1.8 \times 10^{5}$ ind $\mathrm{m}^{-2}$ (at $1200 \mathrm{~m}$ ) to $3.0 \pm 1.2 \times 10^{5}$ ind $\mathrm{m}^{-2}$ (at $1800 \mathrm{~m}$ ), with no significant differences between the three depths (Fig. 2b, Table 2 ). There was a general, although not significant, decrease in biomass with depth (Fig. 2b, Table 2). The total mean meiobenthic biomass varied from a minimum of $9.6 \pm 5.5 \mathrm{mgC} \mathrm{m}^{-2}$ (at $2100 \mathrm{~m}$ ) to a maximum of $19.2 \pm 13.7 \mathrm{mgC} \mathrm{m}^{-2}$ at the shallowest station (at 1200 m; Fig. 2b). The total macrofauna abundance showed means ranging from $557 \pm 312$ ind $\mathrm{m}^{-2}$ (at $1200 \mathrm{~m}$ ) to $365 \pm 144$ ind $\mathrm{m}^{-2}$ at the deepest station (at $2100 \mathrm{~m}$ ), without any significant differences between the three depths (Fig. 2c). Unlike the abundance pattern, there was a clear ( $>10$-fold) and significant decrease in biomass detected with increasing water depth (Fig. 2c, Table 2), with means ranging from $28.2 \pm 14.6 \mathrm{mgC} \mathrm{m}^{-2}$ (at $1200 \mathrm{~m}$ ) to $1.8 \pm 1.0 \mathrm{mgC} \mathrm{m}^{-2}$ (at $2100 \mathrm{~m}$; Fig. 2c).

Figure 3 shows the changes in the biomass contributions to the total benthic biomass (sum of total prokaryote, meiofauna and macrofauna biomass) of each of the benthic components with depth, expressed as the ratios between the benthic standing stocks. The contribution of prokaryotes to the total biomass significantly increased with increasing depth $(\mathrm{p}<0.01)$, due to the large increase in the prokaryote biomass, in con- a)

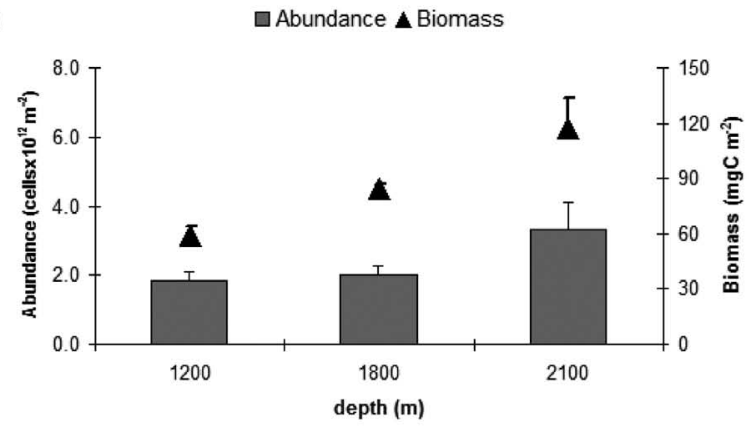

b)

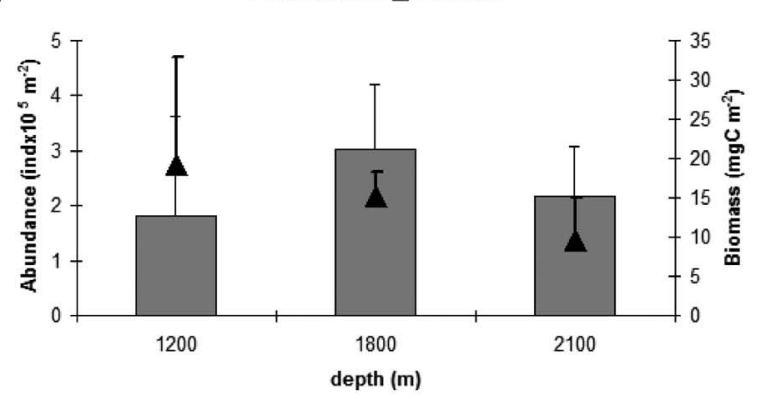

c)

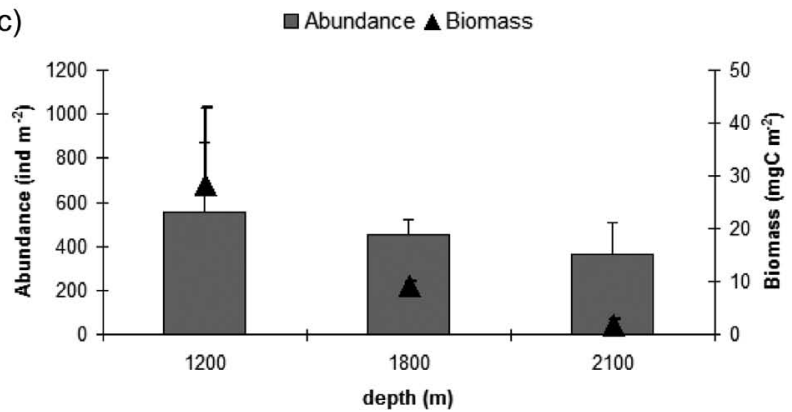

FIG. 2. - Distributions of the different benthic components for the three increasing water depths. (a) Total prokaryote abundance (cells $\left.\times 10^{12} \mathrm{~m}^{-2}\right)$ and biomass $\left.(\mathrm{mgC} \mathrm{m})^{-2}\right)$. (b) Total meiofauna abundance (ind $\mathrm{m}^{-2}$ ) and biomass $\left(\mathrm{mgC} \mathrm{m} \mathrm{m}^{-2}\right.$ ). (c) Macrofauna abundance (ind $\left.\mathrm{m}^{-2}\right)$ and biomass $\left(\mathrm{mgC} \mathrm{m}{ }^{-2}\right)$. Data are means \pm standard deviation.

trast to the meio- and especially macrofauna biomass contributions, which decreased with depth (Fig. 3).

\section{Prokaryote, meiofauna and macrofauna commu- nity structures}

Overall, the number of cells visualized using the EUB338 and ARCH915 probes accounted for 87\% to $92 \%$ of the total prokaryote abundance (Table 3). The abundance of bacteria and Archaea increased with increasing water depth (Table 3), although without showing significant differences (Table 2). The contribution of bacteria to the total prokaryote abundance was always dominant, with similar percentages $(62 \%$ to $70 \%$ ) at all three depths (Table 3 ). The use of specific probes for the domain of the Archaea revealed two major groups at all three depths: Crenarchaeota and Euryarchaeota, with Crenarchaeota always present in greater numbers than Euryarchaeota (Table 3). The 
TABLE 3. - Total and relative abundance of the different components of the prokaryote communities for the three increasing water depths. Data are means and \pm standard deviation.

\begin{tabular}{lcccccccc}
\hline \multirow{2}{*}{$\begin{array}{l}\text { Depth } \\
(\mathrm{m})\end{array}$} & Bacteria & \multicolumn{2}{c}{$\begin{array}{c}\text { Abundance } \\
\text { Archaea }\end{array}$} & Euryarchaeota $\left.10^{8} \mathrm{~g}^{-1}\right)$ & Crenarchaeota & Bacteria & \multicolumn{2}{c}{ Relative abundance $(\%)$} \\
Archaea & Euryarchaeota & Crenarchaeota \\
\hline 1200 & $1.10 \pm 0.26$ & $0.34 \pm 0.13$ & $0.18 \pm 0.03$ & $0.24 \pm 0.07$ & 66.84 & 20.74 & 10.93 & 14.01 \\
1800 & $1.12 \pm 0.01$ & $0.56 \pm 0.01$ & $0.14 \pm 0.06$ & $0.33 \pm 0.05$ & 61.53 & 30.73 & 7.82 & 18.25 \\
2100 & $2.10 \pm 0.04$ & $0.60 \pm 0.12$ & $0.17 \pm 0.01$ & $0.27 \pm 0.06$ & 69.79 & 19.94 & 5.75 & 8.93 \\
\hline
\end{tabular}

relative distribution of Crenarchaeota varied significantly with water depth, with the highest contribution at the intermediate depth (1800 m) (Tables 2, 3).

For the meiofauna community composition, a total of seven major taxa were identified and usually characterized the deep meiobenthic populations: Nematoda, Copepoda with their nauplii, Ostracoda, Kinorhyncha, Turbellaria, Tardigrada and Gastrotricha (Fig. 4a). All of these seven taxa were represented at the intermediate depth station $(1800 \mathrm{~m})$, which was the most diversified of the three depth stations. As expected, at all depths, nematodes were the dominant group, providing from $87 \%$ (at $1800 \mathrm{~m}$ ) to $98 \%$ (at $1200 \mathrm{~m}$ ) of the total meiobenthic abundance. The other taxa were, in order of dominance, Gastrotricha (maximum 9\% at $1800 \mathrm{~m}$, but absent at $1200 \mathrm{~m}$ ) and Copepoda with their nauplii (maximum $3 \%$ at $2100 \mathrm{~m}$ ), with the remaining taxa at $<1 \%$ (Fig. 4a). In terms of biomass the nematodes were confirmed as dominant everywhere, while the contribution to the biomass of the other taxa had the same order of dominance as for abundances (Fig. 4b). The relative contribution of these other taxa to meiofauna biomass, however, was greater than that for abundance. The ANOSIM analysis revealed significant differences in the meiofauna taxa composition between the 1200$\mathrm{m}$ and $1800-\mathrm{m}$ depth stations $(\mathrm{R}=88.9 \%, \mathrm{p}<0.01)$, with the major contribution to this difference formed by Gastrotricha and "others" (52.1\% and 26.3\%, respectively; SIMPER analysis), in terms of both abundance and biomass.

The number of macrofauna taxa decreased with depth, from $10 \pm 1$ at $1200 \mathrm{~m}$ to $8 \pm 2$ at $2100 \mathrm{~m}$, although without showing any significant differences. Polychaeta was the most abundant group, as usual for deep-sea sediments, and their relative contribu-

\section{- MACRO $\square$ MEIO IMICRO}

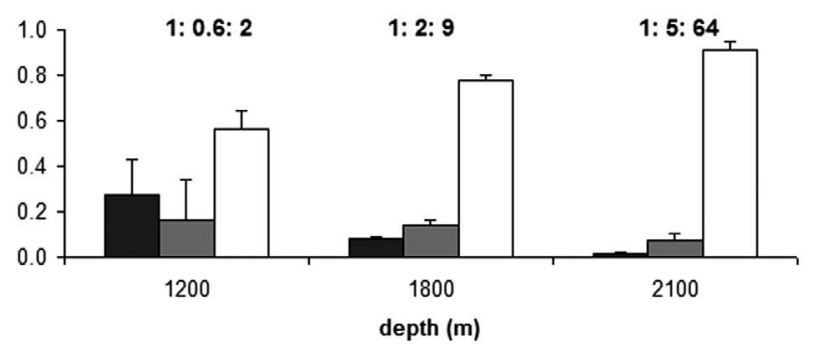

FIG. 3. - Mean ratios for the prokaryotes (MICRO), meiofauna (MEIO) and macrofauna (MACRO) biomass values on total benthic biomass $\left(\mathrm{mgC} \mathrm{m}^{-2}\right)$ for the three increasing depths. Data are means \pm standard deviation. Ratios for macro: meio: micro are also shown. tion to the community structure decreased with depth (from $49.9 \%$ at $1200 \mathrm{~m}$ to $29.2 \%$ at $2100 \mathrm{~m}$; Fig. 5a). Conversely, the macrobenthic nematodes increased in abundance with depth, from $7.5 \%$ at $1200 \mathrm{~m}$ to $21.1 \%$ at $2100 \mathrm{~m}$. The Crustacea, which were mainly represented by Isopoda, Amphipoda and Tanaidacea, were the second most abundant group, with the greatest contribution at $1800 \mathrm{~m}(30.3 \%)$. The Mollusca had the highest contribution at the deepest station $(2100$ $\mathrm{m} ; 20.6 \%$ ), mainly because of the high numbers of Bivalvia, and especially Nucula sp1. The ANOSIM analysis showed significant differences in the macrofauna taxa composition between the 1200-m and 2100-m depth stations ( $\mathrm{R}=100 \%$; $\mathrm{p}<0.01)$, mainly because of Oligochaeta, Sipuncula and Nemertina at the shallowest depth station (1200 m; with their contributions to the dissimilarity of $21.6 \%, 21.7 \%$ and $20.8 \%$, respectively; SIMPER analysis).

The Polychaeta were also dominant in terms of macrofauna biomass (Fig. 5b). At the deepest station $(2100 \mathrm{~m})$, they were accompanied by a high contribu-
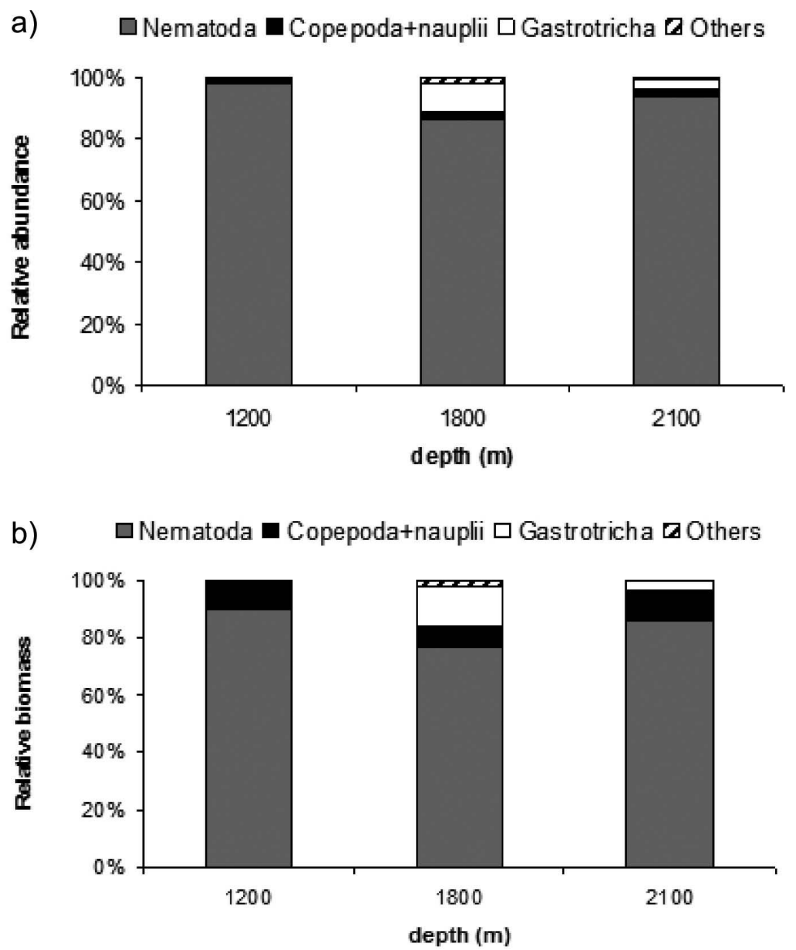

FIG. 4. - Meiofauna community structures for the major taxa for the three increasing water depths, as indicated. (a) Abundance. (b) Biomass. Others: Ostracoda, Kinorhyncha, Turbellaria, Tardigrada combined. 

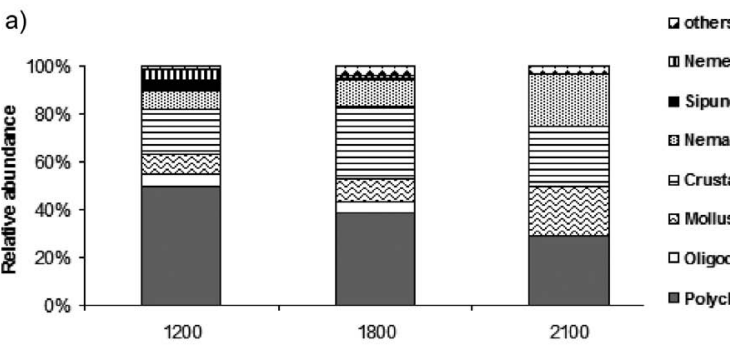

a)

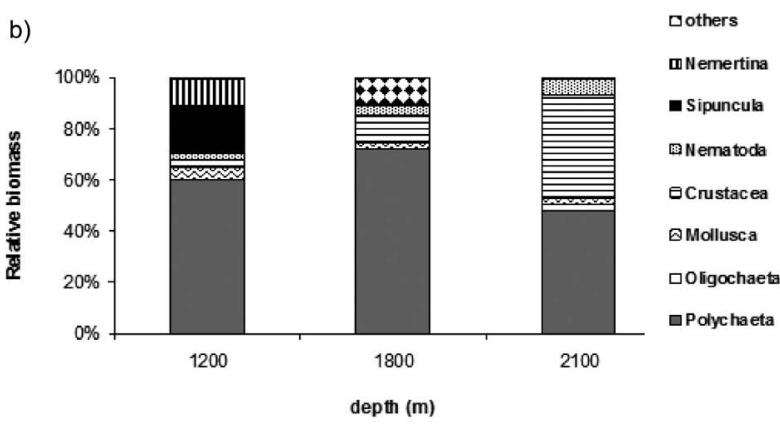

FIG. 5. - Macrofauna community structure of the major taxa (as indicated) for the three increasing water depths. (a) Abundance. (b) Biomass. Others: Hydrozoa, Porifera and Echiura combined.

tion of Crustacea $(33.5 \%)$ because of the presence of large Amphipoda belonging to the families of Phoxocephalidae and Lysianassidae. The Crustacea was the only macrofauna group of which the biomass increased with depth. The Mollusca and macrobenthic nematode contributions to the total macrofauna biomass did not exceed $5 \%$ at any of the depth stations (Fig. 5b). The ANOSIM analysis revealed no significant differences between the three depths in term of the biomass contributions of the different taxa.

\section{Nematode and macrofauna diversities}

Overall, 21 families, 61 genera of Nematoda and a total of 81 species were identified (supplementary information, Table S2). The highest number of families (19) and species (57) was seen at the 1800-m depth station. The species richness or "sample" diversity (i.e. $\alpha$ diversity) of the nematodes is reported in Table 4 . This $\alpha$ diversity (SR) did not change significantly with depth (Table 2), although the diversity and equitability $(\mathrm{J}$ ') indices were greatest at $1800 \mathrm{~m}$ depth. The high values of J' at all of the three depths showed that there

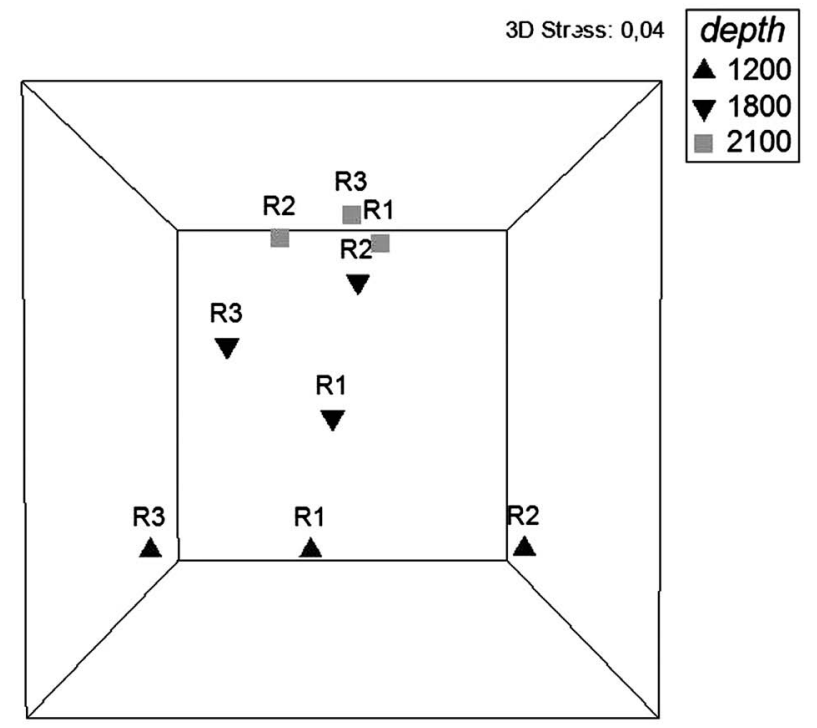

FIG. 6. - Non-metric multi-dimensional scaling ordination plot based on macrofauna species assemblages across the three increasing water depths. All replicates are shown.

were no dominant nematode species (Table 4). The ANOSIM analysis, which was performed to analyse any changes in nematode species composition between the stations at different depths, showed no significant differences in the nematode assemblages. The maturity index ranged from $3.0 \pm 0.1$ (at $1200 \mathrm{~m}$ ) to $3.2 \pm 0.1$ (at $1800 \mathrm{~m}$ ), indicating a greater abundance of nematodes with K-strategies at all three depths, including the genera Halalaimus, Desmoscolex, Leptolaimus and Sphaerolaimus (for a full species list, see supplementary information, Table S2).

A total of 68 macrofauna organisms were identified at the lowest possible taxonomic level (supplementary information, Tables S3 and S4). The macrofauna diversity indices are given in Table 4. As in the $\alpha$ diversity of the nematode composition, none of the diversity indices or the Pielou index of equitability showed any significant differences with increasing water depth. The index of equitability ( $\mathrm{J}$ ') showed an absence of any dominant species also in the macrobenthic communities.

Conversely to what has been reported for nematode compositions, the ANOSIM analysis revealed that the composition of the macrofauna assemblages significantly differed between the $1200-\mathrm{m}$ and 1800 $\mathrm{m}$ stations $(\mathrm{R}=35 \% ; \mathrm{p}<0.05)$ and between the $1200-\mathrm{m}$

TABLE 4. - Diversity indices for the nematodes (meiofauna) and macrofauna for the three increasing water depths. Data are means \pm standard deviation. $\mathrm{H}^{\prime}\left(\log _{2}\right)$, Shannon-Wiener diversity index $\log _{2}$; ES(n), expected species number, as ES(51) for meiofauna and ES(31) for macrofauna; J', Pielou's index of equitability.

\begin{tabular}{|c|c|c|c|c|c|}
\hline & Depth (m) & Species richness & $H^{\prime}\left(\log _{2}\right)$ & $\mathrm{ES}(\mathrm{n})$ & $J^{\prime}$ \\
\hline Meiofauna & $\begin{array}{l}1200 \\
1800 \\
2100\end{array}$ & $\begin{array}{l}25.3 \pm 9.1 \\
31.3 \pm 6.8 \\
30.0 \pm 5.3\end{array}$ & $\begin{array}{l}4.0 \pm 0.3 \\
4.6 \pm 0.2 \\
4.4 \pm 0.2\end{array}$ & $\begin{array}{l}18.3 \pm 5.5 \\
20.1 \pm 2.0 \\
17.3 \pm 3.7\end{array}$ & $\begin{array}{l}0.89 \pm 0.06 \\
0.93 \pm 0.01 \\
0.90 \pm 0.00\end{array}$ \\
\hline Macrofauna & $\begin{array}{l}1200 \\
1800 \\
2100\end{array}$ & $\begin{array}{c}25.3 \pm 11.5 \\
23.7 \pm 3.2 \\
18.7 \pm 5.0\end{array}$ & $\begin{array}{l}4.3 \pm 0.8 \\
4.3 \pm 0.2 \\
3.9 \pm 0.4\end{array}$ & $\begin{array}{l}19.5 \pm 4.0 \\
24.7 \pm 3.1 \\
23.2 \pm 3.1\end{array}$ & $\begin{array}{l}0.94 \pm 0.00 \\
0.93 \pm 0.01 \\
0.93 \pm 0.06\end{array}$ \\
\hline
\end{tabular}


a)

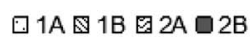

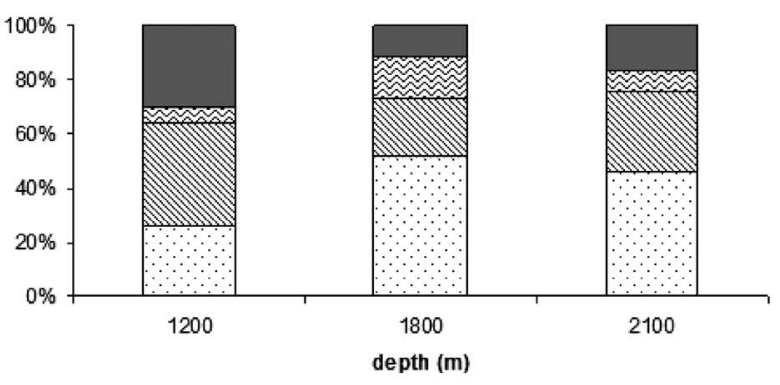

b)

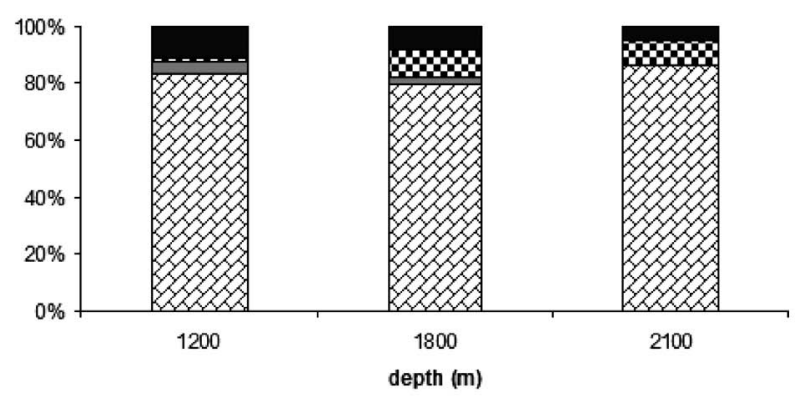

FIG. 7. - Relative proportions of the different trophic groups (as indicated) for the three increasing water depths. (a) Nematodes. $1 \mathrm{~A}$, selective deposit feeders; 1B, non-selective deposit feeders; $2 \mathrm{~A}$, epistrate feeders; $2 \mathrm{~B}$, predators. (b) Macrofauna. SDF, surface deposit feeders; SSDF, sub-surface deposit feeders; FF/SF, filter feeders/suspension feeders; CNV, carnivores/scavengers.

and $2100-\mathrm{m}$ stations $(\mathrm{R}=85 \%$; $\mathrm{p}<0.01)$. The high coefficients of dissimilarities from the SIMPER analysis confirmed the ANOSIM findings: $62.6 \%$ dissimilarity between the $1200-\mathrm{m}$ and $1800-\mathrm{m}$ stations, and $72.7 \%$ dissimilarity between the 1200-m and 2100-m stations. The non-metric multi-dimensional scaling representation in Figure 6 clearly shows the separation between the stations at the different depths.

\section{Nematode and macrofauna feeding guilds}

As expected for deep-sea nematode communities, the two most represented feeding groups at the $1800-\mathrm{m}$ and 2100-m stations were the selective deposit feeders (1A; 52\% and 46\%, respectively). At $1200 \mathrm{~m}$, the most represented were the non-selective deposit feeders (1B; 38\%), which ingest small food particles and bacteria (Fig. 7a). However, the contributions of the other trophic groups were not negligible. The predators (2B) were significantly high at the shallowest station (1200 m; 30.7\%; Fig. 7a), mainly because of Sphaerolaimus spp. The group of epistrate feeders (2A) was significantly more represented at $1800 \mathrm{~m}(15 \%)$, in agreement with the higher CPE. For the Malta Escarpment the nematode ITD index showed mean values ranging from $0.31 \pm 0.01$ (at $1200 \mathrm{~m}$ ) to $0.37 \pm 0.04$ (at $1800 \mathrm{~m}$ ), with no significant differences between the three depth stations.
Considering the macrobenthic trophic structure, the contributions of each trophic group showed no significant differences with depth, in contrast to the nematodes (Table 2). Surface deposit feeders were the most common trophic macrofauna group at all of the stations (Fig. 7b), with a maximum of $87 \%$ at $2100 \mathrm{~m}$ and a minimum of $80 \%$ at $1800 \mathrm{~m}$. The second group was represented by the carnivores and scavengers $(11 \%)$ at $1200 \mathrm{~m}$, mainly because of the Polychaeta, such as Glycera sp., Arabellidae and Syllidae, and the Nemertina. On the other hand, at $1800 \mathrm{~m}$ and $2100 \mathrm{~m}$, the group of filter feeders/suspension feeders $(11 \%$ and $9 \%$, respectively) was the second most represented, because of Bivalvia (Kelliella sp.), Hydrozoa, Porifera, and Polychaeta (Chaetopteridae). There were also subsurface deposit feeders at $1200 \mathrm{~m}$ and $1800 \mathrm{~m}(5 \%$ and $2.3 \%$, respectively). Though surface deposit feeders dominated the community structure, the other trophic groups were not negligible.

\section{DISCUSSION}

\section{Variabilities in the deep-sea benthic components along the Malta Escarpment}

The tremendous geomorphological, hydrographic, geochemical, and biogenic heterogeneity on the seafloor influences the diversity of the margins at multiple spatial scales (Levin and Sibuet 2012). Until recently, the majority of research on these margins focused on slopes with soft sediments (Rex and Etter 2010), which represent by far the most extensive continental margin habitat and are home to one of the most diverse marine communities known (Grassle and Maciolek 1992). The imperative for finding, cataloguing, and understanding margin diversities derives from the many key functions, goods and services provided by continental margin ecosystems, and by the increasingly deep human footprint on our continental slopes (Ramirez-Llodra et al. 2010). Furthermore, a description of multilayer patterns in standing stock and biodiversity that includes the different benthic size components is essential to adopt an integrated approach to the study of deep-sea systems (Boissonas et al. 2002).

A review by Rex et al. (2006) showed overall that there is a significant exponential decrease in both abundance and biomass of meiofauna, macrofauna and megafauna with increasing water depth. Bacterial abundance and biomass, however, show no decline with depth. Our research on the benthic prokaryote abundance and community structure along the Malta Escarpment has provided data that are consistent both with pooled datasets from different regions (Schmidt $e t$ al. 1998, Rex et al. 2006) and with studies carried out at local scales elsewhere in the Mediterranean (Boetius et al. 1996, Deming and Carpenter 2008). Bacteria were the dominant prokaryote component, in agreement with the results from similar hybridization studies carried out in marine sediments (Vetriani et al. 1999, 
TABLE 5. - Spearman rank order correlations between the biological descriptors and environmental variables across the three increasing water depths. Marked correlations are significant at $\mathrm{p}<0.05$ (italic numbers) and $\mathrm{p}<0.01$ (bold numbers). CPE, chloroplast pigment equivalent; PRT/ $\mathrm{CHO}$, protein-to-carbohydrate ratio; BPC, biopolymeric organic carbon; ES(51) and ES(31), expected species number; H'(log $)_{2}$, Shannon diversity index $\log _{2}$.

\begin{tabular}{|c|c|c|c|c|c|c|c|c|c|c|c|c|}
\hline & depth & $\%$ sand & $\%$ silt & $\%$ clay & $\mathrm{CPE}$ & PRT & $\mathrm{CHO}$ & LIP & PRT/CHO & $\mathrm{BPC}$ & cell $\mathrm{m}^{-2}$ & $\mathrm{mgC} \mathrm{m}^{-2}$ \\
\hline yote (ce & 0.843 & -0.264 & 0.843 & -0.843 & -0.500 & -0.600 & 0.150 & -0.900 & -0.683 & -0.750 & 1.000 & 0.900 \\
\hline prokaryc & 0.949 & -0.474 & 0.949 & -0.949 & -0.433 & -0.767 & 0.250 & -0.950 & -0.883 & -0.900 & 0.900 & 1.000 \\
\hline$\%$ EUB & 0.316 & 0.316 & 0.316 & -0.316 & -0.667 & -0.550 & -0.183 & -0.317 & -0.383 & -0.600 & 0.500 & 0.433 \\
\hline$\%$ ARCH & -0.053 & -0.685 & -0.053 & 0.053 & 0.733 & 0.550 & 0.350 & 0.150 & 0.150 & 0.400 & -0.183 & -0.100 \\
\hline$\%$ EURY & -0.685 & 0.422 & -0.685 & 0.685 & 0.383 & 0.667 & -0.400 & 0.600 & 0.867 & 0.750 & -0.450 & -0.750 \\
\hline$\%$ CREN & -0.422 & -0.422 & -0.422 & 0.422 & 0.800 & 0.600 & 0.067 & 0.517 & 0.350 & 0.533 & -0.567 & -0.383 \\
\hline meiofauna (Ind $\mathrm{m}^{-2}$ ) & 0.158 & -0.316 & 0.158 & -0.158 & 0.117 & -0.133 & 0.017 & -0.383 & -0.400 & -0.317 & 0.367 & 0.367 \\
\hline meiofauna ( $\left.\mathrm{mgC} \mathrm{m}^{-2}\right)$ & -0.158 & -0.316 & -0.158 & 0.158 & 0.417 & 0.233 & 0.000 & -0.033 & 0.000 & 0.017 & 0.117 & 0.017 \\
\hline $\mathrm{n}^{\circ} \mathrm{TAXA}$ & 0.485 & -0.888 & 0.485 & -0.485 & 0.358 & -0.009 & 0.562 & -0.562 & -0.536 & -0.264 & 0.426 & 0.485 \\
\hline ITD & 0.369 & -0.580 & 0.369 & -0.369 & 0.167 & -0.067 & 0.350 & -0.367 & -0.400 & -0.217 & 0.333 & 0.483 \\
\hline MI & 0.369 & -0.580 & 0.369 & -0.369 & 0.183 & -0.117 & 0.367 & -0.567 & -0.517 & -0.267 & 0.383 & 0.433 \\
\hline $\mathrm{J}^{\prime}$ & 0.000 & -0.474 & 0.000 & 0.000 & 0.583 & 0.033 & -0.017 & 0.033 & 0.050 & 0.117 & -0.367 & -0.117 \\
\hline $\mathrm{ES}$ & 0.422 & -0.527 & 0.422 & -0.422 & 0.050 & -0.067 & 50 & -0.300 & -0.367 & -0.250 & 83 & 300 \\
\hline$H^{\prime}(\log 2)$ & 0.474 & -0.791 & 0.474 & -0.474 & 0.217 & -0.100 & 0.617 & -0.383 & -0.533 & -0.300 & 0.217 & 0.367 \\
\hline SR & 0.239 & -0.239 & 0.239 & -0.239 & -0.109 & 0.067 & 0.462 & -0.160 & -0.235 & -0.101 & 0.227 & 0.118 \\
\hline $1 \mathrm{~A} \%$ & 0.685 & -0.738 & 0.685 & -0.685 & 0.067 & -0.483 & 0.350 & -0.767 & -0.750 & -0.600 & 0.517 & 0.733 \\
\hline $1 \mathrm{~B} \%$ & -0.399 & 0.718 & & & & & & 0.513 & & & & 20 \\
\hline $2 \mathrm{~A} \%$ & 0.318 & -0.873 & 0.318 & -0.318 & 0.510 & 0.251 & 0.536 & -0.234 & -0.293 & 0.000 & 0.176 & 0.268 \\
\hline $2 \mathrm{~B} \%$ & -0.662 & 0.767 & -0.662 & 0.662 & -0.109 & 0.510 & -0.351 & 0.628 & 0.644 & 0.611 & -0.393 & -0.653 \\
\hline macrofauna & -0.369 & 0.264 & -0.369 & 0.369 & 0.050 & 0.367 & 0.067 & 0.600 & 0.383 & 0.517 & -0.617 & -0.500 \\
\hline macrofauna (mgC m $\left.\mathrm{m}^{-2}\right)$ & -0.949 & 0.474 & -0.949 & 0.949 & 0.417 & 0.750 & -0.217 & 0.917 & 0.850 & 0.883 & -0.883 & -0.983 \\
\hline $\mathrm{n}^{\circ} \mathrm{TAXA}$ & -0.514 & 0.216 & -0.514 & & & 0.607 & & 0.573 & 62 & & 593 & 735 \\
\hline SR & -0.423 & 0.053 & -0.423 & 0.423 & 0.268 & 0.577 & 0.351 & 0.594 & 0.410 & 0.695 & -0.703 & -0.611 \\
\hline $\mathrm{J}^{\prime}$ & 0.105 & 0.264 & 0.105 & -0.105 & -0.450 & -0.150 & 0.333 & -0.200 & -0.150 & -0.050 & 0.100 & 0.000 \\
\hline $\mathrm{ES}(31)$ & -0.264 & -0.105 & -0.264 & 0.264 & 0.300 & 0.617 & 0.500 & 0.383 & 0.350 & 0.667 & -0.483 & -0.517 \\
\hline $\mathrm{H}^{\prime}(\log 2)$ & -0.422 & & -0.422 & & 0.283 & & & 0.533 & & & -0.650 & -0.617 \\
\hline SDF \% & 0.079 & 0.318 & 0.079 & -0.079 & -0.418 & -0.201 & -0.234 & -0.176 & -0.142 & -0.276 & 0.452 & 0.326 \\
\hline SSDF \% & -0.693 & 0.346 & -0.693 & 0.693 & 0.201 & 0.237 & -0.237 & 0.749 & 0.402 & 0.347 & -0.785 & -0.621 \\
\hline $\mathrm{CNV} / \mathrm{SCV} \%$ & -0.265 & 0.291 & -0.265 & 0.265 & -0.033 & 0.134 & 0.050 & 0.142 & 0.285 & 0.268 & -0.243 & -0.385 \\
\hline FF/SF \% & 0.485 & -0.646 & 0.485 & -0.485 & 0.281 & -0.043 & 0.221 & -0.383 & -0.264 & -0.162 & 0.298 & 0.358 \\
\hline
\end{tabular}

Ishii et al. 2004). As shown by other authors (Vetriani et al. 1999, Molari and Manini 2012), Archaea abundance formed a considerable fraction (20\%-30\%) of the deep benthic prokaryote assemblages. Their increasing abundance with water depth is in agreement with other studies (Schippers et al. 2005, Molari and Manini 2012). Looking more in detail at the Archaea composition, the counts for Crenarchaea were higher than those for Euryarchaea at all of the depth stations. A Crenarchaea dominance has been reported in other marine benthic archaeal assemblages (Teske and Sorensen 2008). This finding also agrees with studies in the mesopelagic and bathypelagic domains (Herndl et al. 2005). Furthermore, we also found other archaeal benthic clusters in the deep-sea surficial sediments that were not hybridized by the CREN537 and EURY806 probes. This finding is consistent with previous diversity studies that have reported a complex archaeal population structure of the deep-sea seafloor, and high archaeal diversity in marine sediments (Vetriani et al. 1999, Auguet et al. 2009). The total meiofauna abundance and biomass did not decrease significantly with depth, in contrast with results from other slope areas, where significant decreases in meiofauna stock with depth have been reported (Cartes et al. 2002, Tselepides and Lampadariou 2004); however, the present data are similar to reports by Tselepides et al. (2004) and Lampadariou and Tselepides (2006) from eastern Mediterranean slopes. In the present study, the short bathymetric transect considered may well make it difficult to detect a clear decreasing trend in meiofauna standing stock. Nevertheless, the pronounced inter-replicate variability was consistent with previous studies on small-scale distributions of meiofauna, which have shown that meiobenthic communities can be highly variable even within a few tens of centimetres (De Bovée et al. 1990, Agnes et al. 2011). The mean values of the meiofauna abundance and biomass along the Malta Escarpment correspond to the range of values reported for other slope areas and for bathyal depths along the Mediterranean Sea continental margins (Soetaert and Heip 1995, Tselepides et al. 2004, Lampadariou and Tselepides 2006, just for stations in the Aegean sea), although these are lower in comparison to other areas at similar depths from other oceans (Soltwedel 2000).

Nematodes usually have higher diversity with increasing depth (Coll et al. 2010, Danovaro et al. 2010), although a clear trend of increasing or decreasing nematode diversity and species richness with depth is not always found (Lampadariou and Tselepides 2006). Along the Malta Escarpment, neither the $\alpha$ diversity nor the turnover diversity of the nematode species composition showed significant and clear changes between the depth stations, probably becaue of the many eurybathic nematode genera found at almost all of these depth stations. Some of the most represented genera, such as Halalaimus, Leptolaimus, Syringolai- 
mus, Sabatiera, Sphaerolaimus, Metasphaerolaimus, Linhystera and Desmoscolex, are widespread in the deep sea, and they inhabit a wide bathymetric range and a variety of habitats (e.g., Soetaert and Heip 1995, Lampadariou and Tselepides 2006, Vanreausel et al. 2010). Furthermore, the high values of the maturity indices, which were here always $c a$. 3, showed how all of these depths were characterized by more K-selected genera and stable nematode communities (Hasemann and Soltwedel 2011).

Similar to the meiofauna, the macrofauna abundance along the Malta Escarpment did not decrease with depth, in contrast to some other studies conducted in the central-eastern and western Mediterranean Sea (Kröncke et al. 2003, Mamouridis et al. 2011). On the other hand, there was a lower biomass at the deepest station, following the generally recognized trend of decreased biomass with increased water depth (Rex et al. 2006). The biomass appears to be generally more affected by the depth rather than the density. Indeed, for the macrofauna, Rex et al. (2006) reported a steeper slope of decreasing biomass rather than abundance at increasing water depths. Tselepides et al. (2000) showed a similar trend in the south Aegean sea: a sharper decrease with depth in biomass rather than in the number of macrofauna organisms. Our macrofauna abundances seen here along the Malta Escarpment are greater than those reported for the eastern Mediterranean basin, although the biomass values are similar (Tselepides et al. 2000, Kröcke et al. 2003), and they are higher than those reported in a study conducted in the western Mediterranean basin (Tahey et al. 1994). Comparable macrofauna abundances were found by Kröncke et al. (2003) in the Ionian Sea, though they reported a higher total biomass. Our biomass values are consistent with those reported from stations below $4000 \mathrm{~m}$ in depth by Kröncke et al. (2003). However, comparisons with all of these studies must be made with care, as the mesh sizes used have often differed widely between studies (Soltwedel 2000).

One of the most evident changes in the community structure with increased depth along the Malta Escarpment was a turnover of the abundances of Polychaeta versus the macrobenthic nematodes. Similar changes were seen by Flach and de Bruin (1999) for the Goban Spur slope and by Sharma et al. (2011) in the Gulf of Mexico, where they showed a positive relationship between the dry biomass of the macrobenthic nematodes and the water depth, as in the present study. All of the macrobenthic nematodes identified along the Malta Escarpment belong to the groups of non-selective deposit feeders (1B) and carnivores (2B), as reported by Sharma et al. (2011) and Sharma and Bluhm (2011), and these are functionally different from the meiobenthic nematodes from this area (which mostly belong to groups $1 \mathrm{~A}$ and $1 \mathrm{~B})$.

As along the Malta Escarpment, nematodes of different size classes have been shown to have different functional roles and to partition food sources
(Sharma and Bluhm 2011). The high proportion of deposit-feeding nematodes in the deep sea reflects the important role of bacteria in their nutrition (Danovaro et al. 2008b). Furthermore, the dominance of large detritivores and deposit-feeding nematodes indicates that they play important roles in the carbon recycling in the benthic food web. Predators and omnivores comprised the second most dominant feeding type to characterize these depth stations in the present study. Most predators and omnivores are also facultative scavengers (Heip et al. 1985), and this combination of feeding types is a successful feeding strategy in food-limited habitats, such as the deep sea (Sharma et al. 2011). Also, the gain in importance with depth of molluscs, such as Nucula sp1, and crustaceans, such as Ischnomesidae (Isopoda) and Leptognathia sp1 (Tanaidacea), can be expected, as these are widespread organisms that inhabit the deep sea and that show high plasticity in their feeding strategies (Gage and Tyler 1991). Nevertheless, polychaetes remained one of the most represented groups, with some abundant families, such as Spionidae, Paraonidae, Cirratulidae and Heterospionidae. These have been commonly reported in other studies (e.g. Karakassis and Eleftheriou 1997) as successful inhabitants of the deep sea (Fauchald 1977). Although the values of the $\alpha$ diversity did not change between these depth stations, as was seen for the nematode communities, diversified macrofauna populations emerged at the different depths. The separation between the 1200-m and 1800-2100-m depth stations provided by the non-metric multi-dimensional scaling and confirmed by the ANOSIM analysis indicate a change in the macrofauna composition along the bathymetric gradient that was more evident than was seen for the nematode communities. Additionally, the low coefficient of similarity (36\%) between the replicates from the shallowest depth station indicates a particularly patchy distribution of organisms at 1200 $\mathrm{m}$ depth. Conversely, the deeper communities showed more inter-replicate and among-station homogeneity, in agreement with the idea of a higher homogeneity in benthic populations that characterize the lower slope areas, as suggested by Carney (2005). The differences between the depths was affected by the presence of "rare" species that occurred as singletons or in very low numbers in each sample within the replicates at the same depth (particularly at $1200 \mathrm{~m}$ ), as well as between the depths. This phenomenon has been widely reported in deep-sea macrobenthic communities (Grassle and Macioleck 1992, Rex and Etter 2010).

\section{Contributions of different benthic size classes to total biomass and energy transfer}

A comparison between the biomass estimates of the different benthic components can provide information on the energy transfer pathways in benthic food webs (Albertelli et al. 1999). A more rapid decrease in the macrobenthos standing stock, and generally in the big- 
TABLE 6. - DISTLM-forward analysis: results of the forward selection procedure. Variable, significant explanatory variable(s); SS(Trace), portion of sum of squares relative to the analysed predictor variable; pseudo-F, statistic; $p$, significance level (in italics the significant $p$ values); prop, proportion of variation explained by the explanatory variable.

\begin{tabular}{lcrrr}
\hline & Variable & SS(Trace) & pseudo-F & $p$ \\
\hline Prokaryotic abundance & Depth & 4.2371 & 6.376 & 0.0232 \\
Prokaryotic biomass & \% Clay & 48.2857 & 59.150 & 0.0006 \\
& Depth & 2.9729 & 6.2974 & 0.048 \\
Meiofauna N ${ }^{\circ}$ taxa & \% Sand & 2936.6803 & 7.8967 & 0.89 \\
Nematoda trophic group (2A\%) & \% Sand & 121.5000 & 38.5617 & 0.06 \\
Nematoda trophic group (2B\%) & \% Sand & 661.5000 & 13.9263 & 0.003 \\
Macrofaunal biomass & BPC & 1128.0079 & 17.2322 & 0.0166 \\
\hline
\end{tabular}

ger organisms, is a universal phenomenon that involves complex changes in the relative importance of each of the different size groups (Rex and Etter 1998, Rex et al. 2006). Usually this restriction in size arises from low amounts of food (Wei et al. 2010). In the present study, the significant increase in prokaryote biomass of the total biomass suggests two things: (i) a greater ability of prokaryotes to exploit the organic carbon in the sediments, as compared to the other two benthic classes; and consequently, (ii) a partial channelling of the carbon to the higher trophic levels through the prokaryote component (Danovaro et al. 2000). As deposit feeding is one of the most widely adopted feeding strategies with both meiobenthic and macrobenthic organisms along the investigated area, this suggests grazing on microbes by organisms belonging to the higher trophic levels and could be indicative of a direct food chain, as already described for benthic communities inhabiting food-limited areas (Boetius et al. 1996, Kröncke et al. 2000, Kröncke and Turkey 2003).

\section{Different benthic size classes in relation to the en- vironmental variables}

In energetically stressed environments, such as the deep sea, it is often difficult to identify processes that affect the distribution and abundance of different biotic assemblages. This is because both biological and physical factors are involved, they are not independent, and their relationships with the taxa of interest are frequently non-linear. The amount of CPEs in deepsea sediments has been shown to be a function of the superficial primary production, and of the depth and efficiency of removal along the water column as the particles of organic matter sink to the seafloor (Pusceddu et al. 2010). The overall refractory nature of the autotrophic fractions in the sediments along the Malta Escarpment, which show the very low chlorophyll-a levels of between $0.2 \%$ and $2.6 \%$ of the total CPEs, has also been observed in other deep-sea sediments (Garcia et al. 2007). Despite this, the potential quality of the food that characterizes the Malta Escarpment sediments is closer to the richer western Mediterranean deep sediments than to those of the more oligotrophic east basin or south Adriatic Sea (Pusceddu et al. 2010). This sediment composition also supports a macrofauna community that is dominated by surface deposit feeders at all of these depths, instead of sub-surface deposit feeders and carnivores; indeed, a high percentage of surface deposit feeders is usually associated with medium-to-high quality of organic matter (Wieking 2002, Mamouridis et al. 2011), which confirms that food is one of the most important variables that influence benthic community structures (Mamouridis et al. 2011).

Significant correlations were seen between the macrofauna biomass and the quantity and quality of the organic matter, as well as between the diversity indices and the food availability. The DISTLM analysis (Table 6) confirmed that $71 \%$ of the macrobenthic biomass was explained by the BPC content. Again, the lipid content was positively correlated with the macrofauna biomass, as also previously reported by Cartés et al. (2002). Several studies have recognized that together with food availability and depth, grain size is one of the factors that can shape the benthic communities in the deep sea (Karakassis and Eleftheriou 1997, Stora et al. 1999). This is the case for the macrofauna species distribution along the Malta Escarpment, which is apparently significantly related to the sediment grain size.

If a particular influence of food on the macrobenthic population appears to be clear, for the meiofauna only the group of deposit feeders produced a significant correlation with the prokaryote biomass. The relationships between meiofauna abundance and food quality/ availability are controversial. Several studies have reported a strong influence of food availability not only on the meiofauna standing stock, but also on the diversity (e.g. Garcia et al. 2007, Ingels et al. 2011). Conversely, Hasemann and Soltwedel (2011) showed the same apparent lack of relationship between meiofauna and organic matter content as we see along the Malta Escarpment. Hasemann and Soltwedel (2011) inferred that factors that influence the nematode community have different effects in different areas. Vanhove et al. (1999) underlined that the spatial variability of the meiofauna and the different aggregations are related to different groups of factors (i.e. physical, chemical and biological) that can act together on meiobenthic communities. Soetaert and Heip (1995) and Johnson et al. (2007) indicated that the amount of sedimentary food is not the best proxy for food availability for the benthos, and that there are often no correlations between meiofauna and food. Along the Malta Escarpment, the meiofauna appeared to be more influenced by the sand content, which could explain most of the variability in the diversity (i.e. the number of taxa) and 
feeding groups. The relationship between the benthic communities and the grain size is not unusual in deep sediments (Etter and Grassle 1992), and it has been reported as one of the environmental variables that influences meiofauna distribution, and especially nematodes (Heip et al. 1985).

Along the Malta Escarpment, it here emerges that the differences in prokaryote community abundances are not the result of any single controlling factor, but are the result of the interactions between the different environmental and ecological settings (i.e. grain size, $\mathrm{CPE}$, quality and quantity of organic matter). The abundance of total prokaryotes, Bacteria and Archaea did not show a significant positive correlation with the quantity and availability of the sedimentary organic matter. Along the Mediterranean basin, many other studies have shown that the total prokaryote numbers and biomass are relatively insensitive to variables that are indicative of food availability (Danovaro et al. 1993, Boetius et al. 1996, Tholosan and Bianchi 1998, Bianchi et al. 2003). However, the importance of organic compound resources as a controlling factor of prokaryote assemblages has been confirmed by many other studies (Turley and Dixon 2002, Deming and Carpenter 2008). The discrepancy in these data can be attributed to the presence of different numbers of dead/ dormant cells, as in all of these studies, the relationship was analysed among the total prokaryote parameters and the quantity/availability of organic matter.

It is possible to conclude that different environmental variables can differentially influence each one of these benthic size components along the Malta Escarpment. Other factors not considered in the present study that are fundamental in the shaping of slope benthic communities (e.g. environmental data related to the pelagic realm, such as vertical and later food inputs) must now be taken into further consideration to better explain the community distributions and variabilities.

\section{ACKNOWLEDGEMENTS}

The authors would like to thank Dr. Claudio Vasapollo for providing useful comments and statistical suggestions. This work was carried out in the framework of the EU project BIOFUN (Eurocores EuroDEEP), which is dedicated to the study of the biodiversity in the deep sea. Many thanks also go to the Captain and crew of the RV Urania for their kind assistance during the sampling activities.

\section{REFERENCES}

Agnes M.W.N., Vanreusel A., Vincx M. 2011. Taxon-related diversity patterns from the continental shelf to the slope: a case study on nematodes from the western Indian Ocean. Mar. Ecol. 32: 453-467.

Albertelli G., Covazzi-Harriague A., Danovaro R., Fabiano M., Fraschetti S., Pusceddu A. 1999. Differential responses of bacteria meiofauna and macrofauna in a shelf area (Ligurian Sea, NW Mediterranean): role of food availability. J. Sea Res. 42: 11-26. Andrassy I. 1956. Die Ranminhalts-und Gewichtsbestimmung der
Fadenwurme (Nematoden). Acta Zool. Acad. Sci. Hung. 2: 1-15. Argnani A., Bonazzi C. 2005. Malta Escarpment fault zone offshore eastern Sicily: Pliocene-Quaternary tectonic evolution based on new multichannel seismic data. Tectonics. 24: 12.

Auguet J.C., Barberan A., Casamayor E.O. 2009. Global ecological patterns in uncultured Archaea. ISME J. 4: 182-190.

Bianchi A., Tholosan O., Garcin J., Polychronaky T., Tselepides A., Buscail R., Duineveld G. 2003. Microbial activities at the benthic boundary layer in the Aegean Sea. Progr. Oceanogr. 57: 219-236.

Boetius A., Scheibe S., Tselepides A., Thiel H. 1996. Microbial biomass and activities in the deep-sea sediments of the Eastern Mediterranean: trenches are benthic hotspots. Deep Sea Res. Part I 43: 1439-1460.

Boissonnas J., Connolly N., Mantoura F., d'Ozouville L. (eds) \& contributors, 2002. Integrating Marine Science in Europe. ESF Marine Board Position Paper. 5: 150 pp.

Bongers T. 1990. The maturity index: an ecological measure of environmental disturbance based on nematode species composition. Oecologia. 83: 14-19.

Carney R.S. 2005. Zonation of deep biota on continental margins. Oceanogr. Mar. Biol.: Ann. Rev. 43: 211-278.

Cartés J.E., Grémare A., Maynou F., Villora-Moreno F., Dinet A. 2002. Bathymetric changes in the distributions of particulate organic matter and associated fauna along a deep-sea transect down the Catalan sea slope (northwestern Mediterranean). Prog. Oceanogr. 53: 29-56.

Catalano R., Doglioni C., Merlini S. 2001. On the mesozoic Ionian basin. Geophys. J. Inter. 144: 49-64.

Coll M., Piroddi C., Steenbeek J., Kaschner K., Ben Rais Lasram F., Aguzzi J., Ballesteros E., Bianchi C.N., Corbera J., Dailianis T., Danovaro R., Estrada M., Froglia C., Galil B.S., Gasol J.M., Gertwagen R., Gil J., Guilhaumon F., Kesner-Reyes K., Kitsos M.S., Koukouras A., Lampadariou N., Laxamana E., de la Cuadra C.M.L.F., Lotze H.K., Martin D., Mouillot D., Oro D., Raicevich S., Rius-Barile J., Saiz-Salinas J.I., San Vicente C., Somot S., Templado J., Turon X., Vafidis D., Villanueva R., Voultsiadou E. 2010. The biodiversity of the Mediterranean Sea: estimates, patterns, and threats. PLoS One 5: 1-36.

Danovaro R., Fabiano M., Della Croce N. 1993. Labile organic matter and microbial biomasses in deep-sea sediments (Eastern Mediterranean Sea). Deep Sea Res. Part I. 40: 953-965.

Danovaro R., Marrale D., Della Croce N., Parodi P., Fabiano M. 1999. Biochemical composition of sedimentary organic matter and bacterial distribution in the Aegean Sea: trophic state and pelagic-benthic coupling. J. Sea Res. 42: 117-129.

Danovaro R., Tselepides A., Otegui A., Della Croce N. 2000. Dynamics of meiofaunal assemblages on the continental shelf and deep-sea sediments of the Cretan Sea (NE Mediterranean): relationships with seasonal changes in food supply. Prog. Oceanogr. 46: 367-400.

Danovaro R., Gambi C., Dell'Anno A., Corinaldesi C., Fraschetti S., Vanreusel A., Vincx M., Gooday A.J. 2008a. Exponential decline of deep-sea ecosystem functioning linked to benthic biodiversity loss. Curr. Biol. 18: 1-8

Danovaro R, Gambi C, Lampadariou N, Tselpides A. 2008b. Deepsea nematode biodiversity in the Mediterranean basin: testing for longitudinal, bathymetric and energetic gradients. Ecography 31: 231-244

Danovaro R., Canals M., Gambi C., Heussner S., Lampadariou N., Vanreusel A. 2009. Exploring benthic biodiversity patterns and hotspots on European margin slopes. Oceanogr. 22(1): 16-25.

Danovaro R. 2010. Methods for the study of deep-sea sediments, their functioning and biodiversity. Taylor \& Francis Group, CRC Press, $250 \mathrm{pp}$.

Danovaro R., Company J.B., Corinaldesi C., D’Onghia G., Galil B., Gambi C., Gooday A.J., Lampadariou N., Luna GM., Morigi C., Olu K., Polymenakou P., Ramirez-Lloidra E., Sabbatini A., Sardà F., Sibuet M., Tselepides A. 2010. Deep-sea biodiversity in the Mediterranean Sea: the known, the unknown, and the unknowable. PLoS One 5: 1-25.

De Bovée F., Guidi L.D., Soyer J. 1990. Quantitative distribution of deep-sea meiobenthos in the northwestern Mediterranean (Gulf of Lion). Cont. Shelf Res. 10: 1123-1145.

Deming J.W., Carpenter S.D. 2008. Factors influencing benthic bacterial abundance, biomass, and activity on the northern continental margin and deep basin of the Gulf of Mexico. Deep Sea 
Res. Part II. 55: 2597-2606.

Deprez T., Speybroeck J., Steyaert M., Vincx M. 2005. NeMys. World Wide Web electronic publication. http://www. nemys. ugent.be, version and date accessed (7/2006).

Etter R.J., Grassle J.F. 1992. Patterns of species diversity in the deep sea as a function of sediment particle size diversity. Nature 360: 576-578.

Fabiano M., Danovaro R., Fraschetti S. 1995. A three-year time series of elemental and biochemical composition of organic matter in subtidal sandy sediments of the Ligurian Sea (northwestern Mediterranean). Cont. Shelf Res. 15: 1453-1469.

Fauchald K. 1977. The Polychaete worms. Definitions and keys to the orders, families and genera. Natural Hystory Museum of Los Angeles County, $188 \mathrm{pp}$.

Fauchald K., Jumars P.A. 1979. The diet of the worms: a study of polychaete feeding guilds. Oceanogr. Mar. Biol. Ann. Rev. 17: 193-284.

Flach E. 1999. The meiofauna:macrofauna ratio across the continental slope of the Goban Spur (northeast Atlantic). J. Mar. Biol. Ass. U.K. 79: 233-241.

Flach E. and de Bruin W. 1999. Diversity patterns in macrobenthos across a continental slope in the NE Atlantic. J. Sea Res. 42: 303-323.

Fry J.C. (1990). Direct methods and biomass estimation. Methods Microbiol. 22: 41-85.

Gage J.D., Tyler P.A. 1991. Deep-sea biology: a natural history of organisms at the deep-sea floor. Cambridge University Press, Cambridge, 504 pp.

Galéron J., Sibuet M., Mahaut M.L., Dinet A. 2000. Variation in structure and biomass of the benthic communities at the three contrasting sites in the tropical Northeast Atlantic. Mar. Ecol. Progr. Ser. 197: 121-137.

Galil B.S. 2004. The limit of the sea: the bathyal fauna of the Levantine Sea. Sci. Mar. 68: 63-72.

Garcia R., Koho K. A., De Stigter H.C., Epping E., Koning E., Thomsen L. 2007. Distribution of meiobenthos in the Nazaré canyon and adjacent slope (western Iberian Margin) in relation to sedimentary composition. Mar. Ecol. Progr. Ser. 340: 207-220.

Grassle J.F., Macioleck N.J. 1992. Deep-sea species richness: regional and local diversity estimates from quantitative bottom samples. Am. Nat. 139: 313-341.

Guilini K., Soltwedel T., van Oevelen D., Vanreusel A. 2011. Deepsea nematodes actively colonise sediments, irrespective of the presence of a pulse of organic matter: results from an in-situ experiment. PLoS One 6: 1-12.

Hasemann C., Soltwedel T. 2011. Small-scale heterogeneity in deep-sea nematode communities around biogenic structures. PLoS One 6: 1-13.

Heip C., Vincx M., Vranken G. 1985. The ecology of marine nematodes. Oceanogr. Mar. Biol. Ann. Rev. 23: 399-489.

Herndl G.J., Reinthaler T., Teira E., van Aken H., Veth C., Pernthaler A., Pernthaler J. 2005. Contribution of Archaea to total prokaryotic production in the deep Atlantic Ocean. Appl. Environ. Microbiol. 71: 2303-2309.

Hurlbert S.H. 1971. The non-concept of species diversity: a critique and alternative parameters. Ecology 52: 577-586.

Ingels J., Tchesunov A.V., Vanreusel A. 2011. Meiofauna in the Gollum Channels and the Whittard Canyon, Celtic Margin how local environmental conditions shape nematode structure and function. PLoS One 6: 1-15.

Ishii K., Mussmann M., MacGregor B.J., Amann R. 2004. An improved fluorescence in-situ hybridization protocol for the identification of bacteria and archaea in marine sediment. FEMS Microbiol. Ecol. 50: 203-212.

Jensen P. 1984. Measuring carbon content in nematodes. Helgol. Meeresunters. 38: 83-86.

Johnson N.A., Campbell J.W., Moore T.S., Rex M.A., Etter R.J., McClain C.R., Dowell M.D. 2007. The relationship between the standing stock of deep-sea macrobenthos and surface production in the western North Atlantic. Deep Sea Res. Part I. 54: 1350-1360.

Karakassis I., Eleftheriou A. 1997. The continental shelf of Crete: structure of macrobenthic communities. Mar. Ecol. Progr. Ser. 160: $185-196$.

Kröncke I., Vanreusel A., Vincx M., Wollenburg J., Mackensen A., Liebezeit G., Behrends B. 2000. Different benthic size-com- partments and their relationship to sediment chemistry in the deep Eurasian Arctic Ocean. Mar. Ecol. Progr. Ser. 199: 31-41.

Kröncke I., Turkay M., Fiege D. 2003. Macrofauna communities in the eastern Mediterranean deep sea. Mar. Ecol. 24: 193-216.

Kröncke I., Turkay M. 2003. Structural and functional aspects of the benthic communities in the deep Angola Basin. Mar. Ecol. Progr. Ser. 260: 43-53

Lampadariou N., Tselepides A. 2006. Spatial variability of meiofaunal communities at areas of contrasting depth and productivity in the Aegean Sea (NE Mediterranean). Progr. Oceanogr. 69 19-36.

Levin L.A., Etter R.J., Rex M.A., Gooday A.J., Smith C.R., Pineda J., Stuart C.T., Hessler R.R., Pawson D. 2001. Environmental influences on regional deep-sea species diversity. Annu. Rev. Ecol. Syst. 32: 51-93.

Levin L.A., Sibuet M. 2012. Understanding continental margin biodiversity: a new imperative. Annu. Rev. Mar. Sci. 4: 79-112.

Luna G.M., Manini E., Danovaro R. 2002. Large fraction of dead and inactive bacteria in coastal marine sediments: comparison of protocols for determination and ecological significance. Appl. Environ. Microbiol. 68: 3509-3513.

Mackenzie F.T., Lerman A. 2006. Carbon in the Geosphere-Earth's Outer Shell. Springer, Dordrecht, The Netherlands, 402 pp.

Mamouridis V., Cartés J.E., Parra S., Fanelli E., Saiz Salinas J.I. 2011. A temporal analysis on the dynamics of deep-sea macrofauna: Influence of environmental variability off the Catalonia coast (western Mediterranean). Deep Sea Res. Part I 58: 323-337.

McArdle B.H., Anderson M.J. 2001. Fitting multivariate models to community data: a comment on distance-based redundancy analysis. Ecology 82: 290-297.

Molari M., Manini E. 2012. Reliability of CARD-FISH procedure for enumeration of Archaea in deep-sea surficial sediments. Curr. Microbiol. 64: 242-250.

Narayanaswamy B.E, Renaud P.E., Duineveld G.C.A., Berge J., Lavaleye M.S.S., Reiss H., Brattegard T. (2010). Biodiversity trends along the western European margin. PLoS One 5: 1-19.

Norman A.M., Stebbing T.R.R. 1886. On the Crustacea Isopoda of the Lightning, Porcupine and Valorous expeditions. Smithsonian Institution, Washington, $141 \mathrm{pp}$.

Pape E., Jones D.O.B., Manini E., Bezerra T.N., Vanreusel A. 2013. Benthic-pelagic coupling: effects on nematode communities along southern European continental margins. PloS One 8(4): e59954

Pielou E.C. 1975. Ecological diversity. Wily, New York: pp. 165

Platt H.M., Warwick R.M. 1983. A synopsis of the free living marine nematodes. Part I: British Enoplids. Cambridge University Press, Cambridge.

Pusceddu A., Bianchelli S., Canals M., Sanchez-Vidal A., De Madron X.D., Heussner S., Lykousis V., de Stigter H., Trincardi F., Danovaro R. 2010. Organic matter in sediments of canyons and open slopes of the Portuguese, Catalan, southern Adriatic and Cretan Sea margins. Deep Sea Res. Part I 57: 441-457.

Ramirez-Llodra E., Brandt A., Danovaro R., De Mol B., Escobar E., German C.R., Levin L.A., Arbizu P.M., Menot L., BuhlMortensen P., Narayanaswamy B.E., Smith C.R., Tittensor D.P., Tyler P.A., Vanreusel A., Vecchione M. 2010. Deep, diverse and definitely different: unique attributes of the world's largest ecosystem. Biogeosciences 7: 2851-2899.

Rex M.A., Etter R.J. 1998. Bathymetric patterns of body size: implications for deep-sea biodiversity. Deep Sea Res. Part II 45 103-127.

Rex M.A., Etter R.J., Morris J.S., Crousel J., McClain C.R., Johnson N.A., Stuart C.T., Deming J.W., Thies R., Avery R., 2006. Global bathymetric patterns of standing stock and body size in the deep-sea benthos. Mar. Ecol. Progr. Ser. 317: 1-8.

Rex M.A., Etter R.J. 2010 Deep-Sea Biodiversity: Pattern and scale. Harvard University Press, Cambridge, 354 pp.

Rowe G., Sibuet M., Deming J., Khripounoff A., Tietjen J., Macko S., Theroux R. 1991. 'Total' sediment biomass and preliminary estimates of organic carbon residence time in deep-sea benthos. Mar. Ecol. Progr. Ser. 79: 99-114.

Sanders H.L. 1968. Marine benthic diversity: a comparative study. Am. Nat. 102: 243-282.

Sars G.O. 1882. An account of crustacea of Norway with short description and figures of all the species. The Bergen Museum, Bergen, 255 pp. 
Schippers A., Neretin L.N., Kallmeyer J. 2005. Prokaryotic cells of the deep sub-seafloor biosphere identified as living bacteria. Nature 433: 861-864.

Schmidt J.L., Deming J.W., Jumars P.A., Keil R.G. 1998. Constancy of bacterial abundance in surficial marine sediments. Limnol. Oceanogr. 43: 976-982.

Shannon C.E., Weaver W. 1949. The mathematical theory of communication. University of Illinois, Urbana, IL.

Sharma J., Bhlum B.A. 2011. Diversity of larger free-living nematodes from macrobenthos $(>250 \mu \mathrm{m})$ in the Arctic deep-sea Canada Basin. Mar. Biodiv. 41: 445-465.

Sharma J., Baguley J., Bluhm B.A., Rowe G. 2011. Do meio- and macrobenthic nematodes differ in community composition and body weight trends with depth? PLoS One 6: 1-8.

Soetaert K., Heip C. 1995. Nematode assemblages of deep-sea and shelf break sites in the North Atlantic and Mediterranean Sea. Mar. Ecol. Progr. Ser. 125: 171-183.

Soltwedel T. 2000. Metazoan meiobenthos along continental margins: a review. Progr. Oceanogr. 46: 59-84.

Stora G., Bourcier M., Arnoux A., Gerino M., Le Campion J., Gilbert F., Durbec J.P. 1999. The deep-sea macrobenthos on the continental slope of the northwestern Mediterranean sea: a quantitative approach. Deep Sea Res. Part I 46: 1339-1368.

Tahey T.M., Duineveld G.C.A., Berghuis E.M., Helder W. 1994 Relation between sediment-water fluxes of oxygen and silicate and faunal abundance at continental shelf, slope and deep-water stations in the northwest Mediterranean. Mar. Ecol. Prog. Ser. 104: 119-130.

Teske A, Sorensen K. 2008. Uncultured archaea in deep marine subsurface sediments: have we caught them all? ISME J. 2: 3-18.

Tholosan O., Bianchi A. 1998. Bacterial distribution and activity at the water-sediment boundary layer on NW Mediterranean continental margin. Mar. Ecol. Progr. Ser. 128: 273-283.

Tselepides A., Papadopoulou K.-N., Podaras D., Plaiti W., Koutsoubas D. 2000. Macrobenthic community structure over the continental margin of Crete (South Aegean sea, NE Mediterranen). Progr. Oceanogr. 46: 401-428.

Tselepides A., Lampadariou N. 2004. Deep-sea meiofaunal community structure in the Eastern Mediterranean: are trenches benthic hotspots? Deep Sea Res. Part I 51: 833-847.

Tselepides A., Lampadariou N., Hatziyanni E. 2004. Distribution of miobenthos at bathyal depths in the Mediterranean Sea. A comparison between sites of contrasting productivity. Sci. Mar. 68: 39-51.

Turley C.M., Dixon J.L. 2002. Bacterial numbers and growth in surficial deep-sea sediments and phytodetritus in the NE Atlantic: relationships with particulate organic carbon and total nitrogen. Sci. Mar. 49: 815-826.

Vanhove S., Arntz W., Vincx M. 1999. Comparative study of the nematode communities on the southeastern Weddel Sea shelf and slope (Antarctica). Mar. Ecol. Progr. Ser. 181: 237-256.

Vanreusel A., Fonseca G. Danovaro R., da Silva M.C., Esteves A.M., Ferrero T., Gad G., Galtsova V., Gambi C., da Fonseca
V., Ingels J., Ingole B., Lampadariou N., Merckx B., Miljutin D., Miljutina M., Muthumbi A., Netto S., Portnova D., Radziejewska T., Raes M., Tchesunov A., Vanaverbeke J., Van Gaever S., Venekey V., Bezerra T.N., Flint H., Copley J., Pape E., Zeppilli D., Martinez P.A., Galeron J. 2010. The contribution of deep-sea macrohabitat heterogeneity to global nematode diversity. Mar. Ecol. 31: 6-20

Vetriani C., Jannasch H.W., MacGregor B.J., Stahl D.A., Reysenbach A.L. 1999. Population structure and phylogenetic characterization of marine benthic archaea in deep-sea sediments. Appl. Environ. Microbiol. 4375-4384.

Warwick R.M., Platt H.M., Somerfield P.J. 1998. A synopsis of the free living marine nematodes. Part III: Monhysterids. Synopses of the British fauna (New Series). Field Studies Council, Shwreusbury, 296 pp.

Wei C-L., Rowe G.T., Escobar-Briones E., Boetius A., Soltwedel T., Caley M.J., Soliman Y., Huettmann F., Qu F., Yu Z., Pitcher C.R., Haedrich R.L., Wicksten M.K., Rex M.A., Baguley J.G., Sharma J., Danovaro R., MacDonald I.R., Nunnally C.C., Deming J.W., Montagna P., Lévesque M., Weslawski J.M., Wlodarska-Kowalczuk M., Ingole B.S., Bett B.J., Billett D.S.M., Yool A., Bluhm B.A., Iken K., Narayanaswamy B.E. 2010. Global patterns of predictions of seafloor biomass using Random Forests. PLoS One 5: 1-15.

Wieking G. 2002. The macrofauna at the Dogger bank: Food supply in relation to hydroclimate. $\mathrm{PhD}$ thesis, University of Oldenburg, Germany.

Wieser W. 1953. Beziehungen zwischen Mundhohlengestalt, Ernahrungsweise und Vorkommen bei freilebenden marinen Nematoden. Ark. Zool. 2: 439-484.

Witte U. 2000. Vertical distribution of metazoan macrofauna within the sediment at four sites with contrasting food supply in the deep Arabian Sea. Deep Sea Res. Part II 47: 2979-2997.

Scient. ed.: W.E. Arntz.

Received January 11, 2013. Accepted September 9, 2013.

Published online October 3, 2013.

\section{SUPPLEMENTARY MATERIAL}

The following material is available through the web page http://www.icm.csic.es/scimar/supplm/sm03811SMA.pdf

TABLE S1. - Replicates, depth, prokaryote abundance (cell $\left.\mathrm{g}^{-1}\right)$ and biomass $\left(\mu \mathrm{gC} \mathrm{g}^{-1}\right)$; meiofaunal abundance (ind $10 \mathrm{~cm}^{-2}$ ) and biomass ( $\left.\mu \mathrm{gC} 10 \mathrm{~cm}^{-2}\right)$.

TABLE S2. - List of all nematoda species identified; mean abundance values (ind $10 \mathrm{~cm}^{-2}$ ) for each depth are reported.

TABLE S3. - List of macrofauna organisms identified; mean abundance values (ind $\mathrm{m}^{-2}$ ) for each depth are reported. n.i., not identified.

TABLE S4. - List of macrobenthic nematodes identified; mean abundance values (ind $\mathrm{m}^{-2}$ ) for each depth are reported. 
From microbes to macrofauna: an integrated study of deep benthic communities and their response to environmental variables along the Malta Escarpment (Ionian Sea)

ELISA BALDRIGHI, STEFANO ALIANI, ALESSANDRA CONVERSI, MARC LAVALEYE, MIRENO BORGHINI and ELENA MANINI

Supplementary material 
S2 - E Baldrighi et al.

TABLE S1. - Replicates, depth, prokaryote abundance (cell g-1) and biomass $\left(\mu \mathrm{gC} \mathrm{g}^{-1}\right)$; meiofaunal abundance (ind $\left.10 \mathrm{~cm}^{-2}\right)$ and biomass $\left(\mu \mathrm{gC} 10 \mathrm{~cm}^{-2}\right)$.

\begin{tabular}{|c|c|c|c|c|c|}
\hline Replicate & $\begin{array}{l}\text { Depth } \\
\text { (m) }\end{array}$ & $\begin{array}{l}\text { Prokaryote abundance } \\
\left(\text { cells } \mathrm{g}^{-1}\right)\end{array}$ & $\begin{array}{l}\text { Prokaryote biomass } \\
\left(\mu \mathrm{gC} \mathrm{g}^{-1}\right)\end{array}$ & $\begin{array}{l}\text { Meiofaunal abundance } \\
\text { (ind } 10 \mathrm{~cm}^{-2} \text { ) }\end{array}$ & $\begin{array}{l}\text { Meiofaunal biomass } \\
\quad\left(\mu \mathrm{gC} 10 \mathrm{~cm}^{-2}\right)\end{array}$ \\
\hline $\mathrm{R} 1$ & 1206 & $1.64 \mathrm{E}+08$ & 5.33 & 143.51 & 9.95 \\
\hline R2 & 1246 & $1.89 \mathrm{E}+08$ & 5.78 & 379.41 & 46.17 \\
\hline R3 & 1264 & $1.40 \mathrm{E}+08$ & 4.88 & 24.6 & 1.48 \\
\hline R1 & 1780 & $1.59 \mathrm{E}+08$ & 7.61 & 235.90 & 11.66 \\
\hline $\mathrm{R} 2$ & 1779 & $1.97 \mathrm{E}+08$ & 7.83 & 438.39 & 16.38 \\
\hline R3 & 1768 & $1.92 \mathrm{E}+08$ & 7.39 & 230.01 & 17.39 \\
\hline R1 & 2071 & $3.81 \mathrm{E}+08$ & 12.09 & 271.29 & 15.40 \\
\hline R2 & 2087 & $2.62 \mathrm{E}+08$ & 10.51 & 110.09 & 4.58 \\
\hline R3 & 2120 & $2.59 \mathrm{E}+08$ & 9.15 & 268.34 & 8.78 \\
\hline
\end{tabular}

TABLE S2. - List of all nematoda species identified; mean abundance values (ind $10 \mathrm{~cm}^{-2}$ ) for each depth are reported.

\begin{tabular}{|c|c|c|c|}
\hline \multirow[t]{2}{*}{ Species } & \multicolumn{3}{|c|}{ Depth (m) } \\
\hline & 1200 & 1800 & 2100 \\
\hline Aegialoalaimus & 1 & 2 & 3 \\
\hline Ammotheristus sp1 & 0 & 1 & 1 \\
\hline Ammotheristus sp2 & 0 & 0 & 1 \\
\hline Amphimonhystrella sp1 & 3 & 3 & 4 \\
\hline Amphimonhystrella sp2 & 0 & 0 & 0 \\
\hline Aponema & 0 & 0 & 0 \\
\hline Calligyrus & 1 & 4 & 2 \\
\hline Choanolaimus & 0 & 0 & 0 \\
\hline Chromadorina & 0 & 0 & 1 \\
\hline Cylicolaimus & 0 & 0 & 0 \\
\hline Daptonema & 0 & 0 & 0 \\
\hline Desmoscolex sp1 & 1 & 6 & 1 \\
\hline Desmoscolex sp2 & 0 & 3 & 0 \\
\hline Desmoscolex $\mathrm{sp} 3$ & 0 & 2 & 0 \\
\hline Diplopeltoides & 0 & 0 & 0 \\
\hline Disconema $\mathrm{sp} 1$ & 0 & 1 & 1 \\
\hline Disconema $\mathrm{sp} 2$ & 0 & 0 & 1 \\
\hline Elzalia sp1 & 0 & 1 & 1 \\
\hline Elzalia $\mathrm{sp} 2$ & 1 & 4 & 1 \\
\hline Euchromadora & 0 & 0 & 0 \\
\hline Graphonema & 0 & 0 & 1 \\
\hline Halalaimus sp1 & 2 & 6 & 11 \\
\hline Halalaimus sp2 & 1 & 0 & 0 \\
\hline Halichoanolaimus & 0 & 0 & 0 \\
\hline Haliplectus & 0 & 0 & 0 \\
\hline Hopperia & 0 & 1 & 0 \\
\hline Laimella & 0 & 0 & 0 \\
\hline Leptolaimoides & 0 & 0 & 1 \\
\hline Leptolaimus sp1 & 1 & 6 & 5 \\
\hline Leptolaimus $\mathrm{sp} 2$ & 0 & 6 & 4 \\
\hline Linhystera sp1 & 2 & 5 & 8 \\
\hline Linhystera sp2 & 1 & 0 & 1 \\
\hline Linhomoeus & 0 & 0 & 0 \\
\hline Longicyatholaimus & 0 & 3 & 0 \\
\hline Metacomesoma & 1 & 0 & 0 \\
\hline Metacyatholaimus & 0 & 1 & 0 \\
\hline Metacylicolaimus & 0 & 0 & 0 \\
\hline Metasphaerolaimus sp1 & 4 & 1 & 5 \\
\hline Metasphaerolaimus sp2 & 1 & 0 & 0 \\
\hline Metepsilonema & 0 & 1 & 0 \\
\hline Minolaimus & 0 & 1 & 0 \\
\hline
\end{tabular}

\begin{tabular}{|c|c|c|c|}
\hline \multirow[t]{2}{*}{ Species } & \multicolumn{3}{|c|}{ Depth (m) } \\
\hline & 1200 & 1800 & 2100 \\
\hline Molgolaimus & 0 & 0 & 0 \\
\hline Nannolaimoides & 0 & 0 & 0 \\
\hline Nemanema & 1 & 0 & 2 \\
\hline Oxystomina sp1 & 0 & 1 & 3 \\
\hline Oxystomina sp2 & 1 & 0 & 1 \\
\hline Paracomesoma & 0 & 1 & 0 \\
\hline Paracyatholaimus & 0 & 0 & 1 \\
\hline Paradesmodora & 0 & 1 & 0 \\
\hline Paralinhomoeus & 0 & 0 & 0 \\
\hline Paralongicyatholaimus sp1 & 1 & 1 & 1 \\
\hline Paralongicyatholaimus sp2 & 0 & 0 & 0 \\
\hline Pareudesmoscolex & 0 & 1 & 0 \\
\hline Paroxystomina & 0 & 0 & 0 \\
\hline Pierrickia & 1 & 2 & 1 \\
\hline Polygastrophora sp1 & 2 & 3 & 2 \\
\hline Polygastrophora sp2 & 0 & 0 & 0 \\
\hline Polysigma sp1 & 0 & 1 & 1 \\
\hline Polysigma sp2 & 0 & 1 & 0 \\
\hline Procamacolaimus & 0 & 0 & 1 \\
\hline Prochromadorella & 1 & 0 & 0 \\
\hline Psammonema & 0 & 1 & 0 \\
\hline Pselionema & 1 & 2 & 0 \\
\hline Quadricoma & 1 & 1 & 2 \\
\hline Rhabditis & 0 & 0 & 0 \\
\hline Sabatiera sp1 & 9 & 4 & 9 \\
\hline Sabatiera sp2 & 10 & 3 & 2 \\
\hline Sigmaphoranema & 0 & 1 & 0 \\
\hline Sphaerolaimus sp1 & 1 & 1 & 1 \\
\hline Sphaerolaimus sp2 & 12 & 1 & 1 \\
\hline Sphaerolaimus sp3 & 0 & 0 & 2 \\
\hline Spirinia & 0 & 0 & 0 \\
\hline Syringolaimus sp1 & 1 & 4 & 1 \\
\hline Syringolaimus sp2 & 2 & 0 & 3 \\
\hline Thalassomonhystera & 0 & 0 & 0 \\
\hline Terschellingia sp1 & 3 & 3 & 3 \\
\hline Terschellingia sp2 & 0 & 0 & 0 \\
\hline Terschellingia sp3 & 0 & 0 & 0 \\
\hline Tricoma & 1 & 1 & 1 \\
\hline Trochamus & 0 & 0 & 0 \\
\hline Wieseria & 0 & 0 & 2 \\
\hline
\end{tabular}


TABLE S3. - List of macrofauna organisms identified; mean abundance values (ind $\mathrm{m}^{-2}$ ) for each depth are reported. n.i., not identified.

\begin{tabular}{|c|c|c|c|}
\hline \multirow[t]{2}{*}{ Organism } & \multicolumn{3}{|c|}{ Depth (m) } \\
\hline & 1200 & 1800 & 2100 \\
\hline Ampharetidae sp1 & 4 & 4 & 0 \\
\hline Ampharetidae sp2 & 4 & 0 & 4 \\
\hline Lysianassidae sp1 & 8 & 0 & 4 \\
\hline Phoxocephalidae sp1 & 0 & 4 & 4 \\
\hline Amphipoda & 0 & 4 & 8 \\
\hline Aplacophora_Solenogasters & 4 & 0 & 4 \\
\hline Arenicolidae sp1 & 4 & 0 & 0 \\
\hline Arabellidae sp1 & 12 & 0 & 0 \\
\hline Capitellidae sp1 & 4 & 0 & 0 \\
\hline Chetopteridae sp1 & 0 & 12 & 8 \\
\hline Cirratulidae sp1 & 8 & 0 & 4 \\
\hline Cirratulidae sp2 & 4 & 8 & 4 \\
\hline Copepoda harpacticoida sp1 & 12 & 8 & 4 \\
\hline Copepoda harpacticoida sp2 & 8 & 29 & 17 \\
\hline Copepoda harpacticoida sp3 & 0 & 4 & 12 \\
\hline Cossuridae sp1 & 8 & 12 & 0 \\
\hline Echiurida sp1 & 4 & 0 & 4 \\
\hline Glycera sp1 & 8 & 0 & 0 \\
\hline Glycera $\mathrm{sp} 2$ & 0 & 0 & 0 \\
\hline Heterospionidae sp1 & 46 & 12 & 0 \\
\hline Heterospionidae sp2 & 0 & 66 & 21 \\
\hline Hydrozoa sp1 & 0 & 4 & 0 \\
\hline Hydrozoa sp2 & 0 & 17 & 4 \\
\hline Macrostylidae sp1 & 21 & 46 & 4 \\
\hline Macrostylidae sp2 & 4 & 0 & 0 \\
\hline Leptanthura cf. tenuis & 4 & 0 & 0 \\
\hline Ilyarachnidae sp1 & 4 & 0 & 0 \\
\hline Anthuroidae sp1 & 4 & 0 & 0 \\
\hline Hyssura cf.producta & 4 & 0 & 0 \\
\hline Ischnomesidae sp1 & 0 & 12 & 17 \\
\hline Desmosomidae sp1 & 0 & 8 & 0 \\
\hline Calathura sp1 & 0 & 4 & 0 \\
\hline Isopoda & 4 & 0 & 0 \\
\hline Kellia sp1 & 8 & 4 & 12 \\
\hline Lumbrineris sp1 & 0 & 4 & 0 \\
\hline Magelonidae sp1 & 4 & 12 & 0 \\
\hline Nematoda & 41 & 41 & 79 \\
\hline Nemertina sp1 & 12 & 8 & 0 \\
\hline Nemertina sp2 & 8 & 8 & 0 \\
\hline Nucula $\mathrm{sp} 1$ & 25 & 37 & 54 \\
\hline Oligocaheta sp1 & 12 & 8 & 0 \\
\hline Oligocaheta sp2 & 12 & 4 & 0 \\
\hline Oligochaeta sp3 & 4 & 4 & 0 \\
\hline Oligochaeta sp4 & 0 & 4 & 0 \\
\hline Orbinidae sp1 & 4 & 0 & 0 \\
\hline Ostracoda sp1 & 12 & 4 & 8 \\
\hline Ostracoda sp2 & 12 & 0 & 0 \\
\hline Owenidae sp1 & 0 & 0 & 4 \\
\hline Paraonidae sp1 & 21 & 21 & 17 \\
\hline Paraonidae sp2 & 4 & 4 & 0 \\
\hline Pilargidae sp1 & 0 & 8 & 0 \\
\hline Sipuncula sp1 & 17 & 4 & 0 \\
\hline Sipuncula sp2 & 8 & 0 & 0 \\
\hline Skenea sp1 & 0 & 0 & 4 \\
\hline Spionidae sp1 & 46 & 12 & 17 \\
\hline Spionidae sp2 & 37 & 12 & 4 \\
\hline Spionidae sp3 & 8 & 4 & 0 \\
\hline Spionidae sp4 & 0 & 4 & 0 \\
\hline Spongia sp1 & 0 & 8 & 4 \\
\hline Syllidae sp1 & 12 & 4 & 8 \\
\hline Syllidae sp2 & 4 & 0 & 0 \\
\hline Leptognathia filiformis & 12 & 8 & 0 \\
\hline Leptognathia unguicillata & 4 & 0 & 0 \\
\hline Typhlotanais sp1 & 0 & 0 & 8 \\
\hline Terebellidae sp1 & 4 & 8 & 0 \\
\hline Terebellidae sp2 & 12 & 0 & 0 \\
\hline Terebellidae sp3 & 4 & 0 & 0 \\
\hline Yoldia sp1 & 4 & 0 & 0 \\
\hline Xyluphaga sp1 & 0 & 0 & 21 \\
\hline
\end{tabular}

TABLE S4. - List of macrobenthic nematodes identified; mean abundance values (ind $\mathrm{m}^{-2}$ ) for each depth are reported.

\begin{tabular}{|c|c|}
\hline Species & $\begin{array}{c}\text { Depth (m) } \\
1200\end{array}$ \\
\hline $\begin{array}{l}\text { Linhystera } \mathrm{sp} 1 \\
\text { Monhystera } \mathrm{sp} 1 \\
\text { Oxystomina } \mathrm{sp} 1 \\
\text { Polygastrophora } \mathrm{sp} 1 \\
\text { Pareurystomina } \mathrm{sp} 1 \\
\text { Trissonchulus } \mathrm{sp} 1 \\
\end{array}$ & $\begin{array}{c}12 \\
4 \\
4 \\
0 \\
4 \\
21 \\
\end{array}$ \\
\hline$\underline{\text { Trissonchulus sp1 }}$ & 1800 \\
\hline $\begin{array}{l}\text { Anoplostoma } \mathrm{sp} 1 \\
\text { Belbolla } \\
\text { Linhystera } \mathrm{sp} 1 \\
\text { Oncholaimellus } \mathrm{sp} 1 \\
\text { Polygastrophora } \mathrm{sp} 1 \\
\text { Pareurystomina } \mathrm{sp} 1 \\
\text { Promonohystera } \mathrm{sp} 1 \\
\text { Trissonchulus } \mathrm{sp} 1 \\
\text { Thalassoalaimus } \mathrm{sp} 1 \\
\text { Wieseria } \mathrm{sp} 1 \\
\end{array}$ & $\begin{array}{c}17 \\
4 \\
0 \\
0 \\
12 \\
0 \\
8 \\
17 \\
0 \\
4 \\
\end{array}$ \\
\hline Wieseria $\mathrm{sp} 1$ & 2100 \\
\hline $\begin{array}{l}\text { Daptonema } \mathrm{sp} 1 \\
\text { Monhystera } \mathrm{sp} 1 \\
\text { Oxystomina } \mathrm{sp} 1 \\
\text { Polygastrophora } \mathrm{sp} 1 \\
\text { Pheronus } \mathrm{sp} 2 \\
\text { Wieseria } \mathrm{sp} 1\end{array}$ & $\begin{array}{c}8 \\
12 \\
8 \\
17 \\
29 \\
4\end{array}$ \\
\hline
\end{tabular}

